\title{
BEAUFORT SEA COASTAL EROSION, SEDIMENT FLUX, SHORELINE EVOLUTION, AND THE EROSIONAL SHELF PROFILE
}

By Erk Reimnitz, Scot M. Graves, and Peter W. Barnes

\section{INTRODUCTION}

Two sets of charts published by the U.S. Coast and Geodetic Survey (C\&GS) and the National Ocean Survey (NOS), showing the shorelines for 1950 and for 1980 , respectively, were compared in this study of Alaska's north coast between Drew Point and Prudhoe Bay. The mapping, at a scale of 1:50,000, was done in accordance with national standards for establishing legal boundaries, and is detailed enough to allow accurate and comprehensive delineation of coastline changes within the 30-yr period (see accompanying map sheet).

Previous studies (Dygas and Burrell, 1976; Lewellen, 1977; Hartz, 1978; Hopkins and Hartz, 1978; Cannon and Rawlinson, 1981; Kovacs, 1983; and Naidu and others, 1984) using largely spot measurements from aerial photographs and maps, have documented rapid rates of coastal retreat. These studies also point out large regional differences and rapid changes in island configuration and location over various time spans.
Our 30-year comparison entails complete coverage of the coast within the study area (fig. 1), which is divided into 3 major coastal segments (A-B, B-C, and C-D), and are further divided into 15 sectors (see index map on map sheet). This coverage allows an accurate determination of patterns in coastal erosion rates. The coastal erosion rates together with the sediment yield from upland sources are used to estimate the minimum amount of sediment supplied from the study area to the Beaufort Sea. An attempt was also made to interpret trends in coastal evolution in light of what is known about the unique high-latitude, modern shelf environments. Attempts to extrapolate paleoshorelines from the presently high transgression rates forced consideration of the continental shelf profile, and its evolution through time. These considerations lead to the realization that the arctic marine environment contains elements that are more erosive than its low-latitude counterpart, partly through the abrasive action of sea ice.

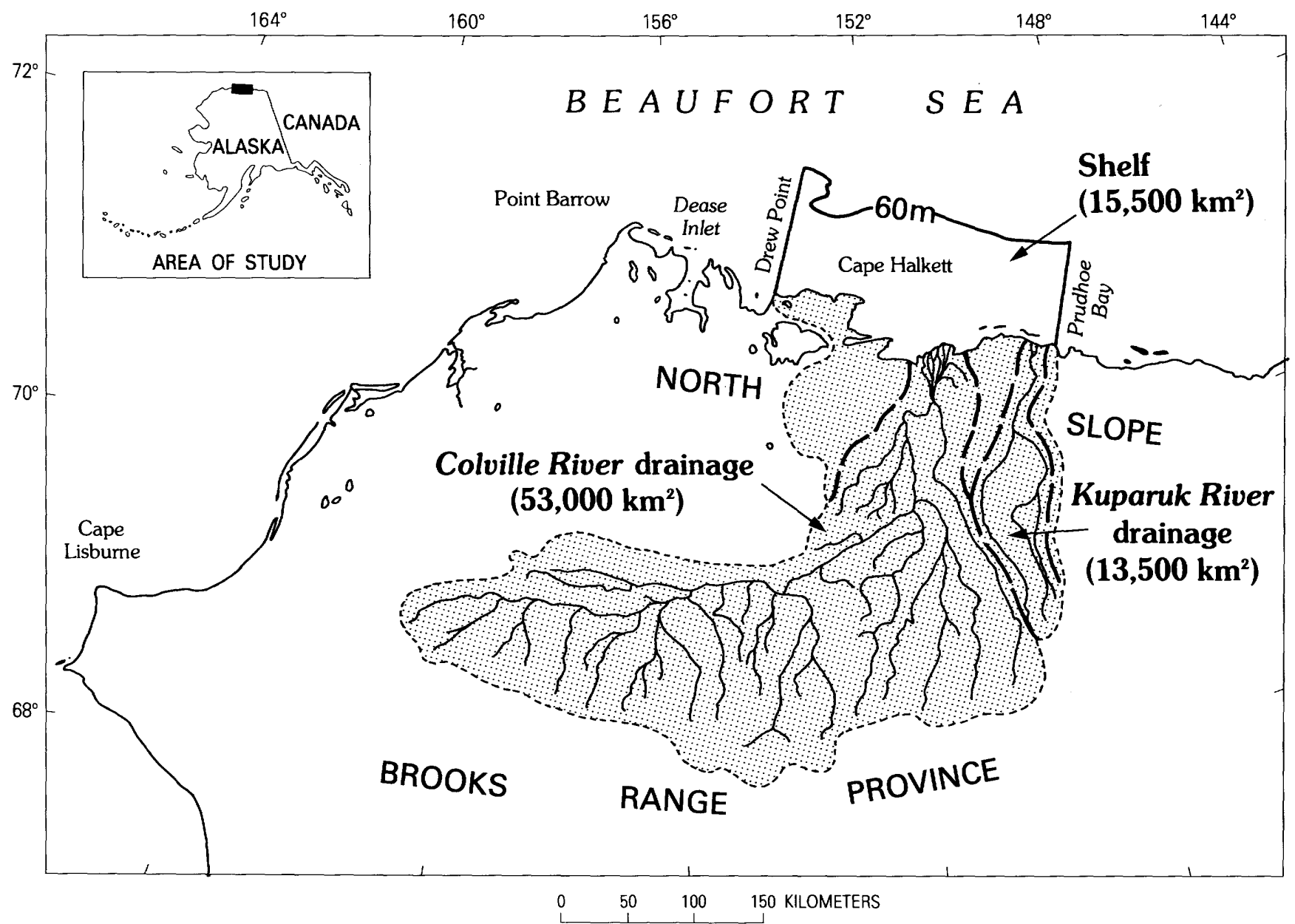

FIGURE 1.- Map of drainage and shelf areas considered in our coastal study along the Beaufort Sea from Drew Point to Prudhoe Bay, northern Alaska. 


\section{REGIONAL SETTING}

\section{PHYSIOGRAPHY AND SURFICIAL DEPOSITS}

The coastal plain in the study area is a vast, flat, tundracovered surface with thousands of shallow (1-2 $\mathrm{m}$ ) thaw lakes (figs. 3,20$)^{1}$. Along the coast this surface is only 2 to $6 \mathrm{~m}$ above sea level, and rises imperceptibly to the south (figs. 3, 5 , and 17). The tundra surface is underlain by the Quaternary Gubik Formation (Black, 1964) whose marine, alluvial, and glacio-fluvial sediments are mantled by $2-3 \mathrm{~m}$ of late Pleistocene and Holocene thaw-lake deposits, consisting mostly of peat and mud (Williams and others, 1977). Except for a seasonal thaw layer (generally as thick as $30 \mathrm{~cm}$ ), the material underlying the tundra surface is permanently ice bonded to a depth of hundreds of meters. In the upper several meters these materials contain 60 to 70 percent ice in grain interstices, and in the form of small but pervasive subhorizontal ice lenses. In addition, these upper sediments contain 10 to 20 percent ice in the form of massive ice wedges (fig. 9 and 10) (Sellmann and others, 1975). Coastal bluffs within the study area generally are 2 to $3 \mathrm{~m}$, and in a few areas as much as $6 \mathrm{~m}$ high. Sandy gravel beaches fronting many of the coastal bluffs are generally about $10 \mathrm{~m}$ wide (figs. 6,11 , and 18 ) and only several tens of centimeters thick. The active mouths of the Kuparuk and the Colville Rivers are marked by low mud flats (figs. 13 and 20), whereas the inactive distributaries are generally marked by $1-m$-high, tundra-covered surfaces (fig. 12). About 5 to $8 \mathrm{~km}$ from shore an island chain stretches from Harrison Bay to Prudhoe Bay. The islands are predominantly low (1-2 $\mathrm{m}$ high) and narrow barriers composed of sand and gravel. Pingok, Bodfish, Bertoncini, and Cottle Islands are exceptions in that they contain remnants of the tundra-covered coastal plain with higher elevations corresponding to adjacent land areas (figs. 18 and 20). Harrison Bay and the stretch of coast from Cape Halkett to Drew Point are not protected by islands, with the exception of the sand bar across the large breached lake at Pogik Bay (fig. 3).

The 2-m isobath, which roughly corresponds to the ultimate thickness of the seasonal fast ice, marks a distinct change from a flat inshore submarine bench to a steeper sloping seaward profile. The outer edge of this so called "2-m bench" (Barnes and Reimnitz, 1973) is often slightly shallower than the waters some distance landward. We include this feature on the map (see map sheet) and in our sediment budget calculations as it is (1) distinctive morphologic feature (Reimnitz and Bruder, 1972), (2) the boundary between texturally well sorted sands inshore, and poorly sorted sandy muds offshore (Barnes and Reimnitz, 1973), (3) controls sea-ice zonation (Reimnitz and others, 1978), and (4) is the outer boundary to which seasonal bottom freezing occurs (Reimnitz and Barnes, 1974). In Harrison Bay, the 2-m bench is as much as $10 \mathrm{~km}$ wide whereas elsewhere it is only 0.5 to $5 \mathrm{~km}$ wide.

\section{WAVE EXPOSURE}

The sea surface is completely ice covered for 9 months each year (fig. 3), and even during the short open-water season,

\footnotetext{
${ }^{1}$ Figures 2 through 20 are found on the map sheet numbered sequentially in an easterty direction along the coast.
}

fetch and waves are minimized by the abundance of drifting ice (figs. $14 B$ and 20). On any typical summer day, a skiff can therefore safely land on a seaward-facing beach (fig. 19), while in the lagoons the relatively ice-free conditions can produce greater wave activity. Even during rare periods when much of the continental shelf is free of sea ice, some grounded ice usually accumulates and remains in the nearshore zone. Winds from the northeast dominate, and coastal currents, movement of the littoral drift, and ice drift are primarily to the west (Mathews, 1981).

\section{SHORE PROCESSES}

Nummedal (1979) reviewed available littoral transport estimates and concluded that the average rate of transport is westward at a "a few tens of thousands of cubic meters per year". A more thorough evaluation of Beaufort Sea coastal processes by Owens and others (1980) quotes a transport rate of 2,000 to $5,000 \mathrm{~m}^{3} / \mathrm{yr}$. Reimnitz and Kempema (1983) give similar transport rates for bedload movement for a several kilometerwide coastal belt, based on measurements made along the outer part of the 2-m bench, several kilometers from shore. This transport also is mainly to the west due to prevailing easterly winds.

The sediment transport is not driven by waves and currents alone. In fact, the active and passive role played by sea ice in the nearshore may be even more important for sediment dynamics, but the mechanisms are poorly known and can not be quantified.

When worked by storm waves (fig. 16A), or when influenced by currents, grounded ice acts to intensify turbulence, resulting in increased sediment suspension and transport, and a highly irregular "ice-wallow relief" is imparted to the beach and nearshore areas (Reimnitz and Kempema, 1983) (figs. 7 and 16). This irregular relief, when in turn attacked by normal waves in the absence of grounded ice, results in increased bottom instability, sediment resuspension, and transport. During open-water storm conditions, these combined processes can act in a coastal belt $1,000 \mathrm{~m}$ or more wide, producing accelerated bottom erosion and a steepening of the foreshore. This steepening of the foreshore in turn should result in accelerated coastal retreat. Under such conditions, as much as $30 \mathrm{~m}$ of coastal-plain deposits can be eroded within a period of several days (Short and others, 1974).

Considering the ice-bonded nature of the coastal deposits, and that air and ocean temperatures are at or near the freezing point, factors other than the energy level of the marine environment affect coastal processes. In most cases, retreat of the coastal bluffs involves the process of thermo-erosion that includes the following: (a) formation of a thermo-erosional niche, when a turbulent sea is brought in contact with bluffs (figs. 9, 10, 11, and 18), (b) collapse of bluff materials (figs. 2 and 5), (c) slumping, and (d) flow of water-saturated, thawed sediments. The mechanisms are described in detail by Harper (1978). A prerequisite for initiation of these mechanisms is that sea level overtop the protecting beach. Summer storms normally blowing from northeasterly directions result in a lowering of sea level and exposure of the upper part of the 2$\mathrm{m}$ bench with waves breaking some distance from the bluffs. The development of a thermo-erosional niche therefore is most commonly seen during westerly winds, which raise sea level 
in the Beaufort Sea, and particularly during storm surges (Reimnitz and Maurer, 1979). While storm surges are rare, bluff erosion probably contributes the largest amounts of sediment to the sea during these short periods. At these times sediment transport is eastward, opposite to the long-term westward movement (Reimnitz and Maurer, 1979). The highest rates of thermo-erosion associated with niche development occur in areas of fine-grained, ice-rich, coastal-plain deposits, which are widespread in the western third of the study area. In these areas, the sparsity of sand and gravel in eroded bluff material does not permit the formation of beaches (fig. 5).

In the littoral zone and on the beaches along the Canadian Arctic and Chukchi Sea coasts, seasonal variations in the depth to the upper surface of ice-bonded sand and gravel have been monitored (for example, Harper and others, 1978, Taylor, 1980). The bonded and presumably erosion-resistant materials are generally less than $1 \mathrm{~m}$ below the sediment surface both at the beach and at wading depths near the beach. According to theoretical calculations (Harper and others, 1978, Taylor, 1980) maximum thaw rates of only 50 to $70 \mathrm{~cm} /$ day are indicated during storm conditions, when thermal diffusivity is increased by high ground-water flow rates, and when sediments released can be removed at the same rate as the frost table retreats, thereby always maintaining direct sea-water contact with ice-bonded sediments. Because rates of coastal changes in the Beaufort Sea are higher than theoretical considerations would permit, Harper and others (1978) speculated that here ice-bonding may not be as widespread as on the Canadian and Chukchi coasts. However, permafrost studies, for example by Morack and Rogers (1981), and our own probing with rods indicate shallow ice bonding along the Beaufort Sea coast beaches and in the nearshore. Morack and Rogers (1981) found that the cores of rapidly migrating barrier islands (Reindeer and Cross Island, $10 \mathrm{~km}$ east of the study area) contain only sporadic bonding. According to results from jet drilling on these islands, the nonbonded materials seem to be brine pockets (T.E. Osterkamp, oral commun., 1985). Such patchy ice bonding suggests that the shoreline configuration of these islands during storm erosion should show corresponding irregularities. However, we have observed these islands under many storm conditions, and never noted irregularities in beach configuration caused by variations in degree of ice bonding and erodability. Therefore, and because of the very high shore retreat rates during single storms, we believe that ice bonding of sediments does not retard beach dynamics during the openwater season.

The onset of winter, with decreasing water temperature, produces conditions that have received very little study. In many polar regions, the formation of an ice foot (Owens, 1982) alters nearshore processes. There are many forms and types of ice foot (Dionne, 1973), and a treatment here is not necessary. Once formed, an ice foot armors the beach, arrests erosion, and in many cases should even result in beach accretion. The fact that sediment layers are interbedded with ice during growth of the ice foot implies sediment movement from inshore areas up onto the beach and foreshore, and consequent steepening of the shoreface. In rare instances, an ice foot does form along the beaches of the Alaskan Beaufort Sea coast (Short and others, 1974). However, our observations over many years during the winter and spring, and during fall storms with and without adequate fetch for wave generation, lead us to believe that ice foot is of little consequence to Beaufort Sea coastal processes. We have observed sediments on the beach face to be ice bonded during cold storms, but erosion nevertheless proceeds rapidly by ripping slabs of bonded sand and gravel from the beach (fig. 14C) and moving these in the swash zone, still intact, for some distance along the beach. During such times the back of the active beach generally is defined by a vertical cliff 1 to $1.5 \mathrm{~m}$ high of icebonded sand and gravel (fig. 14C).

Littoral processes previously undocumented for polar seas are those related to the formation of underwater ice (Martin, 1981 ) in the surf zone. Anchor ice is one form of underwater ice produced when water is so agitated at subfreezing temperatures that an ice cover can not form. Under these conditions, the water becomes slightly supercooled and ice nucleates on the sea floor. This process is well documented in high-latitude streams (Arden and Wigle, 1972; Tsang, 1982; Osterkamp, 1978), but is little understood in the marine environment. Our own observations made during three different fall storms, each with 25 knot or stronger winds and air temperatures of $-10^{\circ} \mathrm{C}$, indicate that in marine waters less than $2 \mathrm{~m}$ deep, bottom sediments become ice bonded. In one instance, a 150-m diving traverse from the beach to 5-m water depth (Reindeer Island, October 1982) revealed ice-bonded sand and gravel interbedded with ice layers in a 30 -m-wide zone near shore. From the $2-\mathrm{m}$ isobath seaward the sea floor was not ice-bonded but instead covered with pillow-size masses of ice (fig. 8). The ice pillows consisted of an outer $(10 \mathrm{~cm}$ thick) rind of fragile ice platelets and a massive, sediment laden core. These observations were made immediately after a three-day storm, during which the bottom may well have been completely ice covered. The effects of this observed ice-bonding and of anchor-ice formation on coastal processes during fall storms is a matter of speculation. Our sketchy observations serve to demonstrate how little is actually known about arctic nearshore processes during times of severe fall weather; yet it is during this period that the greatest coastal changes occur. A very different kind of anchor ice, formed from fresh water, is reported in the Canadian Archipelago (Sadler and Serson, 1981), but has not been seen along the Alaskan Beaufort Sea coast.

A final littoral process to consider is that of bulldozing of shoreface materials by ice onto seaward facing beaches and barrier islands (Hume and Schalk, 1964; Barnes, 1982; McLaren, 1982; Kovacs, 1983). In some years, the sediment volumes so contributed to arctic beaches are considerable. Hume and Schalk (1964) estimated that in one case as much as 10 percent of the beach material above sea level near Barrow had been transported there from offshore by ice push, but that a more typical figure would be 1 to 2 percent. In our study area, the process occurs mainly on those stretches of coast facing the open ocean and rarely in protected lagoons. The resulting ice/sediment piles normally contain sand and gravel-size material that is left as hummocks after the ice melts (fig. 15). The process was unusually active during the winter of 1982-83, based on more than a decade of our observations in the study area. The chain of islands from Thetis through Cottle Island, a distance of $42 \mathrm{~km}$, was marked by sand and gravel piles with average estimated volumes of at least $1 \mathrm{~m}^{3} / \mathrm{m}$ of shoreline. A $6-\mathrm{m}$ high, $20-\mathrm{m}$ wide, and $1-\mathrm{km}$ long rubble pile on Spy Island was covered with very large sediment volumes consisting of sand and gravel. The sedi- 
ment included pockets of clean sand. Bottom grab samples collected along a transect seaward from the ice pile in the direction from which the ice shove originated showed a gravel bottom out to $40 \mathrm{~m}$ from the beach, at $4-\mathrm{m}$ depth, where the first clean sand was retrieved. That point therefore gives the minimum distance for the origin of the sand in the ice pile. While ice-bulldozing during some years helps restore to the beach and shoreface a part of what is removed by waves, currents, and other processes, we feel that its overall contribution is small.

\section{METHODS}

Retreat rates were obtained for the roughly $344 \mathrm{~km}$ of coastline by comparing two sets of charts at a scale of 1:50,000 covering the north coast of Alaska between Drew Pt. and Prudhoe Bay. This comparison shows changes in the position of the shoreline, referenced originally to mean lower low water (MLLW) by the C\&GS, and lately by NOS. Some previous studies of coastal erosion focused on bluff retreat, which over short time periods is not always the same as shoreline retreat. For this reason our numbers locally differ from previously published ones, but overall show the same pattern.

The study area was divided into three major segments in order to present the overall coastline on the map (see map sheet) at the desired resolution. The index map of the map sheet serves as a key to these three major coastal segments and the 15 subdivisions used in our calculations. The original C\&GS charts (numbers 9466 through 9472) represent the coastline configuration in 1949-1952. The new NOS charts depict the coastline as mapped by the State of Alaska in 1980. The seaward extent of the eroding coastal zone considered in our calculations is the position of the $2-\mathrm{m}$ isobath. Since the bathymetry was not resurveyed in connection with the recent mapping effort, but stems from the original 1949-52 charts, we simply shifted the position of the $2-\mathrm{m}$ isobath (map sheet) landward in tandem with local shoreline retreat. A previously uncharted shallow basin in an embayment off sector 9 was delineated by our own bathymetric surveys in 1980 .
A few small areas not covered by the NOS charts were dealt with by comparing the 1949 coastline on U.S. Geological Survey (USGS) topographic maps with the 1980 data. The maps were brought to a common scale and projection and changes in the coastal configuration were registered using the same methods applied in the rest of the study area. Areas treated in this manner (southern part of sector 6, west and east borders of sector 11, and central part of sector 14) are identified on the map sheet.

For convenience of discussion, we divided the coast into 15 sectors based on morphologic and geologic similarities. To calculate sediment input from coastal erosion, each of these sectors in turn was divided into 500 -m-long segments numbered from west to east along the coast. The segments were then treated individually.

\section{GENERALIZED NEARSHORE GEOMETRY}

Quantitative estimates of the sediment introduced by coastal erosion are based on the application of a generalized nearshore geometry (fig. 21) for each $500-\mathrm{m}$ segment. In this model geometry, segment length, bluff height, changes in shoreline position, and distance to the 2-m isobath are measured values; whereas the width, slope, and thickness of the offshore component, and the indicated secondary prism dimensions are calculated values. The general model geometry distinguishes between the two different sources of sediment released to the sea during coastal retreat: (1) The sediment contained in the bluffs between the 1949 and 1980 coastal outlines, and (2) the volume eroded offshore between the new and old nearshore profiles out to the 2-m isobath. For a few particular segments (approximately 14 percent of those studied) alternative geometries were applied. These are described under "Special Case Geometries" (fig. 23). Tabulated in Reimnitz and others (1985) are all measured and calculated values, and parameters assumed in determining the sediment contribution from each of the $500-\mathrm{m}$ segments comprising the 15 sectors.

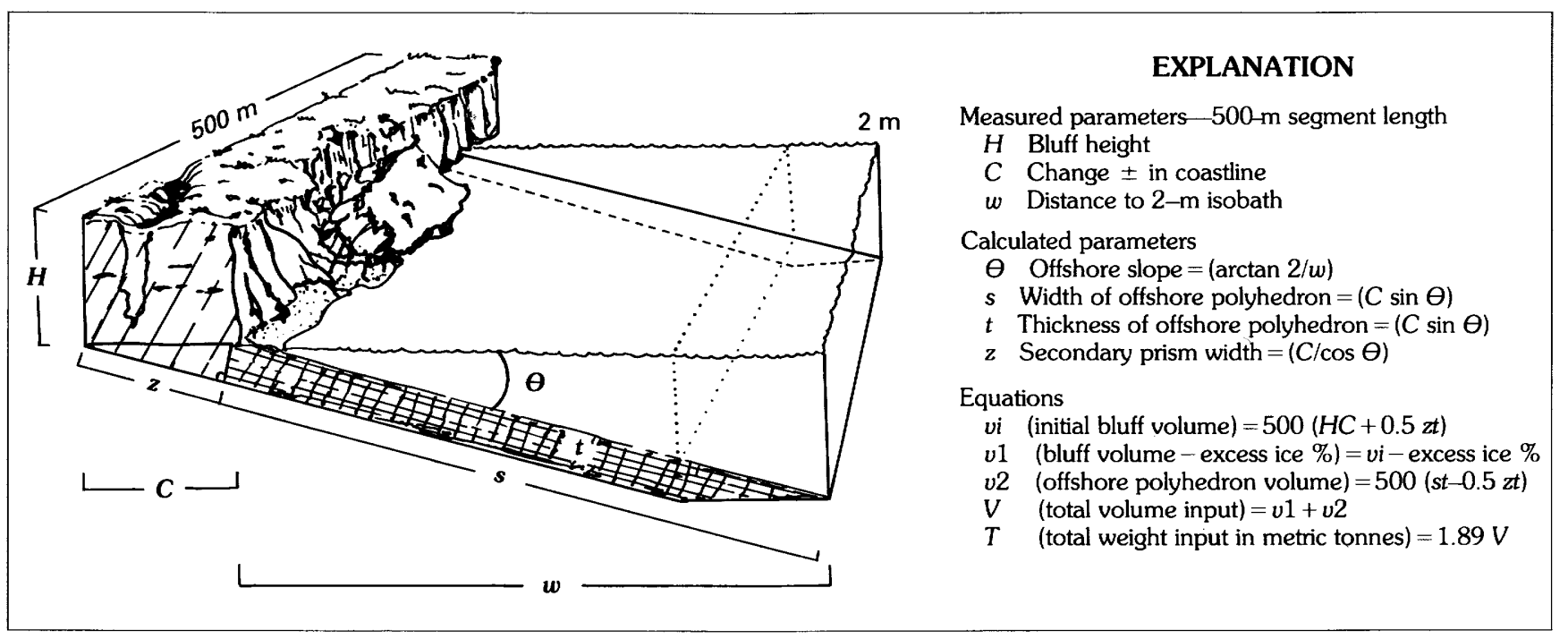

FIGURE 21.-General geometry used for volume calculations. 


\section{SEDIMENT YIELD FROM BLUFF EROSION}

To calculate the sediment contribution from bluff erosion we used the 30-year coastal retreat distance (assuming bluff and shoreline retreat in tandem), bluff height, and the ice content of the eroded material (figs. 21, 22). Because the topographic elevations presented on published maps generally are several meters too high (Lewellen, 1977), we used in our calculations bluff heights from the field notes of D.M. Hopkins, S.E. Rawlinson, Erk Reimnitz, and P.W. Barnes. In determining percentage of excess ice for the coastal-plain sediments, we referred to a data compilation by Sellmann and others (1975), giving excess ice content versus depth below the tundra surface for coastal-plain deposits of the Gubik Formation near Barrow, Alaska (fig. 22). The eroded bluff materials in sectors 7 through 15 are coarser grained than those near Barrow, and therefore our assumed ice percentages here are probably too high. However, in the rapidly eroding sectors 1 through 6 the coastal-plain deposits are very similar in lithology, and therefore presumably ice content, to those at Barrow. Sellmann and others (1975) assume an in situ after-thawsettlement porosity of 35 to 40 percent, while we assume that marine dispersal of sediment results in deposits of only 30 percent porosity.

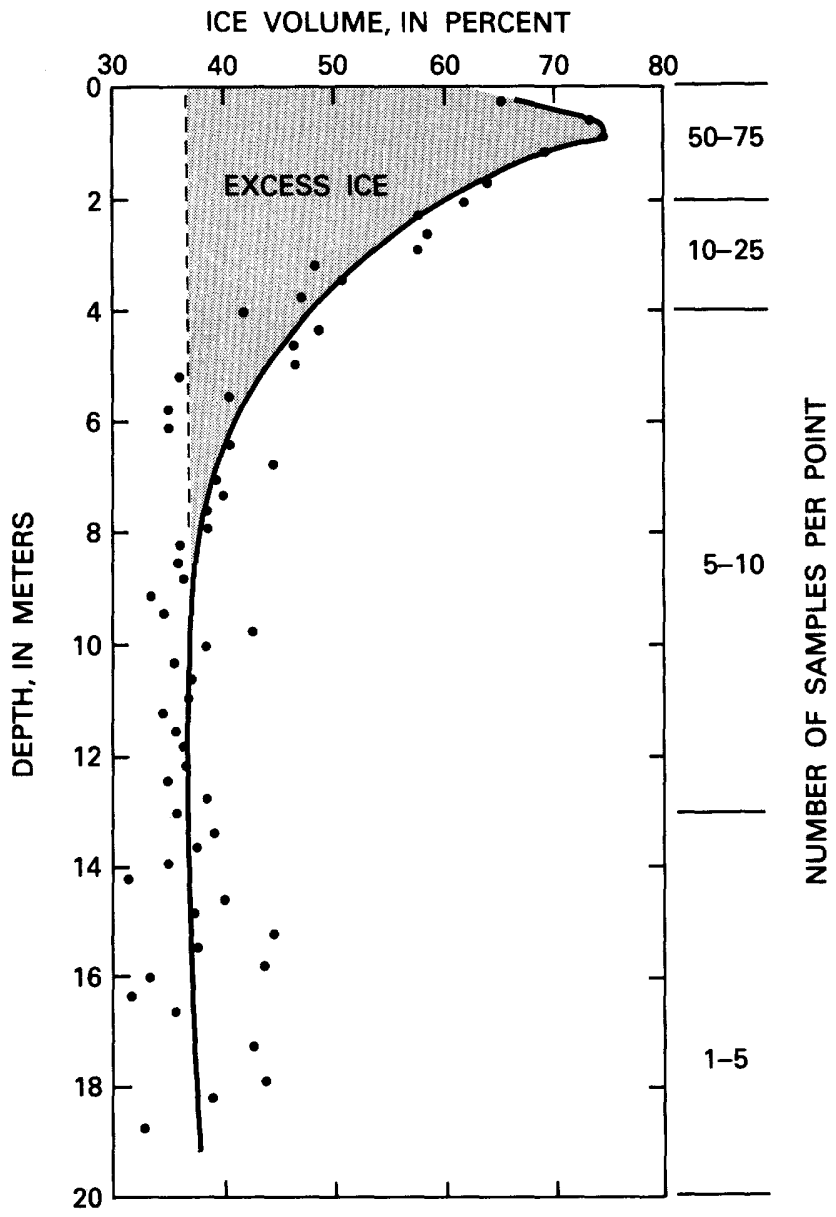

FIGURE 22. Segregated ice volume (exclusive of wedge ice) versus depth below tundra surface (from Sellmann and others, 1975). Curve represents average ice volume; dashed line, post-thaw sediment porosity.
In progradational or accreting areas of the coast, we calculated volume additions for above sea-level material assuming elevations of $20 \mathrm{~cm}$ and $40 \mathrm{~cm}$ for delta mud flats, and beaches and spits, respectively. The use of these particular values is based upon estimates from our field observations.

\section{SEDIMENT YIELD FROM OFFSHORE EROSION}

To calculate sediment contributions to the sea from the erosion of sea-floor material between the shoreline and the 2-m isobath, we assume that the slope of the sea floor in this area of the nearshore is in dynamic equilibrium and remains constant as the shoreline retreats. This assumption is based on our local marine surveying experience. The distance of a vessel from the coast and the corresponding water depths, at almost any location; match those indicated on 30-year-old published nautical charts. This coincidence, and serious questions concerning the maintenance of such an "equilibrium profile" are discussed in detail in a following section using a site in the western part of the study area as an example.

The geometry of the eroded offshore areas and how we normally calculated the resulting sediment volumes is shown (fig. 21). We assume no excess ice for the reworked offshore layer, which generally is only 10 to $20 \mathrm{~cm}$ thick (see sector tabulations 1-15, Reimnitz and others, 1985). Assigning excess ice percentages (fig. 22) for the submerged layer changes our total volume estimates by at most 10 percent.

Where the $2-\mathrm{m}$ isobath is highly crenulated, we arbitrarily smoothed it for our measurements. In the previously uncharted area off sector 9, where published charts place the 2-m isobath at 11 to $14 \mathrm{~km}$ from shore, we attempt to reduce possible errors by introducing bathymetry delineated from our own surveys in 1980 .

\section{SPECIAL CASE GEOMETRIES}

There are several exceptions to the general approach outlined in the previous section. The primary differences lie in deviations from the idealized geometry to more closely approximate the dimensions and resulting volumes for unique local configurations. In all of these instances, the special case geometries applied are identified and keyed to the particular segments concerned (sector tabulations, Reimnitz and others, 1985; figs. 23A-D).

In sector 14 (Simpson Lagoon), where maximum water depths are less than $2 \mathrm{~m}$, the offshore volume considered takes the form of a triangular prism of lagoon-floor material whose apex is at the deepest central point of the lagoon (fig. 23A). The geometry applied here assumes that as the coastline retreats, there is no corresponding shift of the offshore margin, and its depth remains constant.

Two of the remaining three exceptions to the general geometry depict settings in which the landward shift of a relatively steep nearshore profile results in the removal of a substantially thicker prism of offshore material. In one case (fig. $23 B$ ) the distance covered by the retreating coastline is greater than the distance measured from the shore to the position of the 2-m isobath. This situation is common in the Cape Halkett area (sectors 5 and 6 ). We believe that using the general model here might result in values that are excessive relative to our generally conservative estimates for the offshore sediment 
yield. The second such case occurs where onshore migration of a spit or barrier and accompanying shift of the adjacent nearshore profile likewise results in the removal of a very thick offshore prism (fig. 23C). Examples of these type areas are Pitt Point and Pogik Bay. In the Jones/Return Island chain (sector 15) we assumed no volume change for the sand and gravel barrier islands (tan colored in fig. 20). Even at the scale used in this study, we were unable to resolve net volume changes in these barrier islands, and treated them as migrational bodies. Their motion is westward, obliquely onshore, or longshore, thereby adding to the overall westward nearshore sediment transport, but not to the shelf sediment budget. Similarly for the Eskimo Islands (sector 7), which like the cores of certain members of the Jones Islands presently are stationary coastal-plain remnants, we were unable to resolve net changes in the overall volume. Here erosion of westerly exposed tundra bluffs appeared to be compensated for by accretion on adjacent and leeward beaches and spits.

The last exception to the general model deals with areas of actively accreting or prograding shorelines. Here we assumed a seaward shift of the shoreface and offshore profile, with prograding mud flats and beaches at respective elevations of 20 $\mathrm{cm}$ and $40 \mathrm{~cm}$ (fig. 23D). In the overall summary of volumes and weights, the net gain calculated for these areas was subtracted to arrive at the final sediment yield.

A

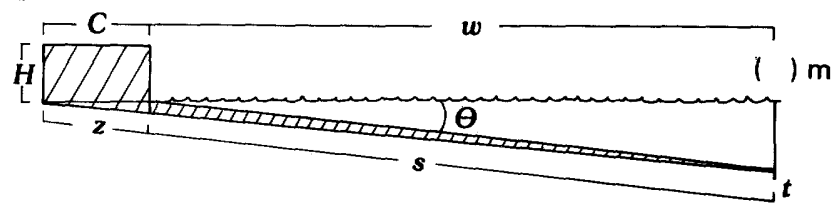

B

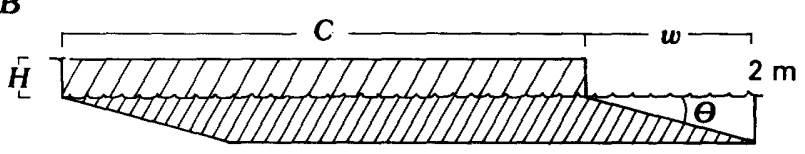

C

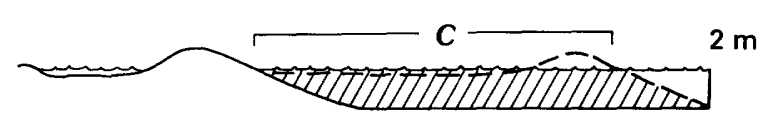

D

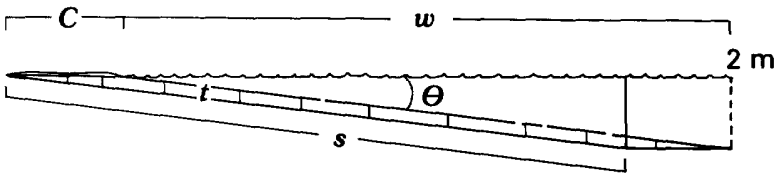

FIGURE 23.--Special case geometries. A, Where segment borders lagoon with a maximum depth $<2 \mathrm{~m}, v i=500$ $(H C+0.5 z t), v 1=v i-$ excess-ice percent, $v 2=0.5(500$ st $) . B$, Where $C>w, v i=500 H C, v 1=v i-$ excess-ice percent, $v 2=$ $500 C 2$. $C$, Where barrier or spit shifted onshore $v i=0, v 1$ $=0, v 2=500 C 2$. $D$, Where accretion has occurred $v i=v 1=$ $+500 H C, v 2=+500$ st. See fig. 21 for symbols explanation.

\section{RESULTS}

Tabulations for each of the 15 sectors showing both measured and calculated values used to determine the sediment yield from coastal retreat are given in Reimnitz and others (1985). A summary of sediment yields for the entire area is given here (table 1$){ }^{2}$

TABLE 1.-Summary of annual sediment yield from coastal erosion and river input from Drew Point to Prudhoe Bay, northern Alaska

[Overall erosion rate, $2.1 \mathrm{~m} / \mathrm{yr}$ (without Coville delta sector, $2.4 \mathrm{~m} / \mathrm{yr}$ ): combined drainage area, $74,000 \mathrm{~km}^{2}$; average denudation rate, $10 \mathrm{ukm}^{2}$ ]

\begin{tabular}{lcccc}
\hline \multirow{2}{*}{ Source } & \multicolumn{2}{c}{ Volume $\left(10^{3} \mathrm{~m}^{3}\right)$} & \multicolumn{2}{c}{ Weight $\left(10^{3} \mathrm{t}\right)$} \\
\cline { 2 - 5 } & Per $\mathrm{km}$ & Total & Per $\mathrm{km}$ & Total \\
\hline \multicolumn{5}{c}{ Coastal Erosion } \\
\hline Bluffs & 3.5 & 1,200 & 6.6 & 2,300 \\
Offshore & 3.8 & 1,300 & 7.2 & 2,500 \\
\cline { 2 - 5 } Total & 7.3 & 2,500 & 13.8 & 4,800 \\
\hline \multicolumn{5}{c}{ River input } \\
\hline Total & - & 394 & - & 740 \\
\hline
\end{tabular}

The average rate of coastal retreat for the $344 \mathrm{~km}$ of coastline studied is $2.1 \mathrm{~m} / \mathrm{yr}$. This rate includes accretionary shoreline changes along the large Colville River system, where 48 $\mathrm{km}$ of coastline have advanced an average of $0.4 \mathrm{~m} / \mathrm{yr}$. Excluding the delta, the erosion rate is $2.5 \mathrm{~m} / \mathrm{yr}$. After subtracting excess ice from the eroded bluffs, we calculate the total annual sediment contribution from subaerial erosion from the entire study area to be 1.2 million $\mathrm{m}^{3}$. This number represents the sum of the sediment yields from all segments and divided by 30 years. Using the same approach, we estimate the annual sediment contribution from erosion in the offshore (submarine) to be 1.3 million $\mathrm{m}^{3}$. The total annual sediment yield from coastal erosion therefore is 2.5 million $\mathrm{m}^{3}$. To help visualize the significance of this sediment volume one can prorate this for the Holocene $(10,000 \mathrm{yrs})$ and spread it over the present continental shelf adjoining the study area $\left(15,500 \mathrm{~km}^{2}\right.$, see fig. 1). The resulting sediment layer would be $1.6 \mathrm{~m}$ thick. However, as discussed in the following section, the offshore erosion associated with the present transgression is not restricted to coastal waters of less than 2-m depth. The inner- and mid-shelf areas are a surface undergoing erosion and therefore overall sediment yields may be many times larger than our calculations indicate.

Available sediment textures are listed (table 2) for coastalplain deposits exposed in bluffs along the Beaufort Sea. Two of the bluff sections listed, Christie Point (long $155^{\circ} 35^{\prime} \mathrm{W}$.) and Tigvariak Island (long $147^{\circ} 15^{\prime} \mathrm{W}$.), are outside of the study area. The former is considered representative of the fine-grained deposits found in sectors 1 through 6 . The latter,

${ }^{2} \mathrm{An}$ error in the original tabulation of excess ice in bluff materiais was corrected. The recalculated sediment yield sums excess ice values for all $500-\mathrm{m}$ segments at $1 / 2-m$ elevation increments. While the new values increased or decreased by as much as 20 percent according to bluff height in particular segments, the total yield in table 1 is unchanged. 
an abnormally coarse grained section and as far as we know without counterpart in the study area, is included to suggest the variability of coastal-plain deposits along the Alaskan Beaufort Sea. The only information on the amount of organic matter contained in the bluffs comes from S.E. Rawlinson's (written commun., 1983) extensive work around Simpson Lagoon. The figure of 40 percent he obtained is probably representative of bluff compositions for the entire region.

TABLE 2.-Clastic component for coastal-plain deposits exposed in bluffs along the Arctic coast

\begin{tabular}{|c|c|c|c|c|}
\hline $\begin{array}{l}\text { Sample } \\
\text { location }\end{array}$ & $\begin{array}{l}\text { Percer } \\
\text { gravel }\end{array}$ & $\begin{array}{l}\text { at grair } \\
\text { sand }\end{array}$ & $\begin{array}{l}\text { n size } \\
\text { mud }\end{array}$ & Reference \\
\hline $\begin{array}{l}\text { Oliktok Pt. } \\
\text { and } \\
\text { Kavearak Pt. }\end{array}$ & 0 & 69 & 31 & $\begin{array}{l}\text { R. I. Lewellen } \\
\text { (written commun., } \\
\text { 1973)(average } \\
\text { of } 2 \text { samples) }\end{array}$ \\
\hline $\begin{array}{l}\text { Simpson } \\
\text { Lagoon }^{1}\end{array}$ & 0 & 85 & 15 & $\begin{array}{l}\text { S. E. Rawlinson } \\
\text { (written commun., } \\
\text { 1983)(average } \\
\text { of } 60 \text { samples) }\end{array}$ \\
\hline Tigvariak Isl. $^{2.3}$ & $\begin{array}{l}2.6 \\
2.5\end{array}$ & $\begin{array}{l}62.9 \\
61.9\end{array}$ & $\begin{array}{l}34.5 \\
35.6\end{array}$ & $\begin{array}{l}\text { Reimnitz and Barnes } \\
\text { (unpub. data, } \\
\text { 1983)(average } \\
\text { of } 2 \text { samples) }\end{array}$ \\
\hline $\begin{array}{l}\text { Atigaru Pt. } \\
\text { Drew Pt. } \\
\text { Teshekpuk L. } \\
\text { Christie Pt. }^{3}\end{array}$ & $\begin{array}{l}0 \\
0 \\
0 \\
0\end{array}$ & $\begin{array}{c}85 \\
8 \\
42 \\
32\end{array}$ & $\begin{array}{l}15 \\
92 \\
58 \\
68\end{array}$ & R. F. Black (1964) \\
\hline
\end{tabular}

'Organic component as much as 41 percent of overall bluff composition. ${ }^{2}$ Chosen for its unusually high concentration of gravel.

${ }^{3}$ Location outside of study area.

\section{DISCUSSION}

\section{REGIONAL PATTERNS IN COASTLINE RECESSION}

There are large regional variations in the rate of shoreline retreat from the 30-yr average of $2.1 \mathrm{~m} / \mathrm{yr}$. Extremes range from a retreat rate of $18 \mathrm{~m} / \mathrm{yr}$ near Cape Halketh, to an accretion rate of $20 \mathrm{~m} / \mathrm{yr}$ near the active mouths of the Colville drainage system (map sheet). There is a pronounced disparity in erosion rates between the western and eastern parts of the study area. The western part (sectors 1-6, but exclusive of Pogik Bay with its unique setting) is composed of fine-grained coastal-plain deposits, with average retreat rates of $5.4 \mathrm{~m} / \mathrm{yr}$. The coastal plain in the eastern part of the study area is composed of sandy sediments. Here the average retreat rate, exclusive of the Colville River delta, is $1.4 \mathrm{~m} / \mathrm{yr}$.

Long-term changes in the configuration of coastlines are dependent on a combination of various climatic and oceanographic factors, as well as composition and geometry of the coastal plain transgressed. Severe short-term episodes of coastal erosion may locally play a dominant role in the overall evolution of the coastline. An example is the single storm event of several days duration in 1972 (Short, 1973), in which almost $30 \mathrm{~m}$ of bluff was removed from the seaward facing shores of Pingok Island. During intervening years bluffs may locally appear entirely stabilized.

An understanding of regional differences in erosion rates in terms of geologic and oceanographic setting would allow reconstruction of past shorelines, and the prediction of future trends in coastal evolution. Certain factors known to influence erosion rates along the Beaufort Sea coast are discussed in the following section.

Vertical movement of the Earth's crust has affected some parts of Alaska's coastal evolution. The consistent elevation $(7 \pm 3 \mathrm{~m})$ of the Pelukian shoreline from Barrow to the Colville River (Hopkins and Carter, 1980) is strong evidence that this stretch of coast has been stable for the past 120,000 years. Thus, Dease Inlet and Smith Bay, two of northern Alaska's most pronounced embayments, can not have been produced by differential vertical motion during that time period. According to Hopkins and Hartz (1978) the coarse-grained, coastal-plain deposits cropping out in the Jones Islands may also be Pelukian beach deposits. If correct, such deposits would extend at a uniform level throughout the entire study area, except for a gap in eastern Harrison Bay. From examination of our seismic records of the region, industry borehole data, and from on-land studies of the Quaternary geology (David Carter, oral commun., 1985), there is no evidence for Holocene subsidence of Harrison Bay, and this break in the supposed continuous Pelukian beachline remains unexplained.

Mean sea levels for the summer months from 1975 to 1984 were measured by the NOS at the east end of sector 14 (fig. 24). The best fit line for that data indicates a sea-level rise of $2 \mathrm{~cm} / \mathrm{yr}$ or $2 \mathrm{~m} / 100 \mathrm{yr}$. This is much higher than the worldwide sea-level rise of 0.1 to $0.15 \mathrm{~m} / 100 \mathrm{yr}$ and therefore suggests subsidence of that area. The configuration of shallow subbottom seismic reflectors in the region, in particular that of the post-Pelukian unconformity offshore, does not support local subsidence (Wolf and others, 1985). Furthermore, the modern coastal retreat rates in the area of the tide gauge are among the lowest of the entire study area. Thus we can find no support for the 9-yr sea-level trend shown by summer tidal data. The gauge has been operated for only 2 to 3 months each summer and is located on a recently constructed gravel causeway. On this causeway are the reference benchmarks used to reestablish the gauge each summer. Most of these are lost each year due to causeway maintenance work. Moreover, the causeway serves for the transport of single modules weighing 1,000 tons or more. For these reasons we regard the tidegauge data as unreliable for the purpose of establishing a sealevel trend.

An important data set on relative sea-level changes was obtained during the recent mapping project, when tidal bench marks from the original 1950 work were reoccupied. At five locations between Pitt Point (see map sheet) and the Canadian border a total of sixteen benchmarks were referenced to a new tidal datum obtained from one-and-a-half year observations near Prudhoe Bay. The observed changes in benchmark elevations (table 3) suggest an increase in elevation relative to sea level, except at the Demarcation Bay site, where submergence of 3 to $5 \mathrm{~cm}$ is suggested for the 29-yr observation period. The indicated elevation increases may be attributed to the fact that the new sea-level datum is based on over one year of 
data, while the old datum stems from relatively short summer observations, when sea level in the Beaufort Sea is universally higher (Jim Spargo, State of Alaska, Coastal and Marine Boundary Section, oral commun., 1985). Monitoring of tidal bench marks indicates no significant vertical crustal movement of Alaska's north coast during the study period.

All information available to us therefore suggests that irregularities in coastline configuration within the study area have not been produced by differential vertical crustal motion during Holocene time.

Bluff height is one of the dominant factors controlling rates of erosion (Owens and others, 1980). In areas of high bluffs, where large sediment volumes are made available by melting, the marine energy in some seasons is simply inadequate to remove material at the rate at which it is introduced into the nearshore. The introduced materials are seen on beaches and

TABLE 3.-Thirty-year changes in tidal benchmark elevations from 1951 to 1981

[Extracted from Project Report, Contract: GSC-376 by Alaska Photogram metric Consultants Group, 1982 and 1983 for the State of Alaska, Anchorage]

\begin{tabular}{|c|c|c|c|}
\hline $\begin{array}{l}\text { Location } \\
\text { (long W.) }\end{array}$ & $\begin{array}{l}\text { Benchmark } \\
\text { identification }\end{array}$ & $\begin{array}{l}\text { Years } \\
\text { observed }\end{array}$ & $\begin{array}{l}\text { Changes }(\mathrm{cm}) \\
\text { relative to } \\
\text { MLLW }\end{array}$ \\
\hline $\begin{array}{l}\text { Lonely } \\
\left(153^{\circ} 05^{\prime}\right)\end{array}$ & $\begin{array}{l}\text { Camp } \\
\mathrm{rm} 1 \\
\mathrm{rm} 2\end{array}$ & $\begin{array}{c}1951-1981 \\
\text {-do- } \\
\text {-do- }\end{array}$ & $\begin{array}{r}-1 \\
+21 \\
+7\end{array}$ \\
\hline $\begin{array}{l}\text { Flaxman Island } \\
\left(146^{\circ} 03^{\prime}\right)\end{array}$ & $\begin{array}{l}1 \\
2 \\
3\end{array}$ & $\begin{array}{c}\text { 1950-1981 } \\
\text {-do- } \\
\text {-do- }\end{array}$ & $\begin{array}{l}+6 \\
-1 \\
-1\end{array}$ \\
\hline $\begin{array}{l}\text { Simpson Cove } \\
\left(144^{\circ} 49^{\prime}\right)\end{array}$ & $\begin{array}{l}\text { A } \\
\text { B } \\
\text { C } \\
D \\
\text { E }\end{array}$ & $\begin{array}{c}1950-1981-82 \\
\text {-do- } \\
\text {-do- } \\
\text {-do- } \\
\text {-do- }\end{array}$ & $\begin{array}{r}+10 \\
+6 \\
+7 \\
+5 \\
+6\end{array}$ \\
\hline $\begin{array}{l}\text { Barter Island } \\
\left(143^{\circ} 37^{\prime}\right)\end{array}$ & $\begin{array}{l}2 \\
4\end{array}$ & $\begin{array}{c}1951-1981 \\
\text {-do- }\end{array}$ & $\begin{array}{r}+14 \\
+5\end{array}$ \\
\hline $\begin{array}{l}\text { Demarcation Bay } \\
\left(141^{\circ} 12^{\prime}\right)\end{array}$ & $\begin{array}{l}1 \\
2 \\
3\end{array}$ & $\begin{array}{c}\text { 1952-1981 } \\
\text {-do- } \\
\text {-do- }\end{array}$ & $\begin{array}{l}-3 \\
-4 \\
-5\end{array}$ \\
\hline
\end{tabular}

in the swash zone in various forms, waiting for a surge with wave action to remove them. Areas that lack bluffs (fig. 6) on the other hand, are quickly inundated upon contact with the sea due to the extremely large amounts of ice in the upper $2 \mathrm{~m}$ of coastal-plain deposits and the resulting thaw collapse. Here, little lateral transport of sediment, or 'marine energy', is required to inundate the coastal plain. High bluffs along the Chukchi coast are partly responsible for the much lower erosion rates there than along the Beaufort Sea coast (Harper, 1978). Similarly, high bluffs in the Kogru River area are probably in part responsible for the lower erosion rates there than at Cape Halkett, although in this case the degree and direction of exposure and bluff lithology are perhaps the dominant factors.

The presence or absence of a beach, and its volume and dimensions, strongly affect the coastal-retreat process. Broad and high beaches are rarely overtopped by the sea, reducing thermal processes to ineffective atmospheric summer warming. One such area is the north coast of Pingok Island where for reasons as yet not well understood, the coarse gravelly beach broadened, even advanced, during the study period, while the bluff line continued to retreat. This is an area where the eroding offshore profile is cutting into underlying gravel (fig. 31) and may be the source for replenishing the beaches, as the eroding bluff contains almost no gravel clasts. If so, this would call for ice bulldozing as the transport agent feeding the beach. Because this study compares shorelines, while others may have considered the changes in the bluff line only, our erosion rates may differ from previously published values. The Pingok Island retreat rates (fig. 31) are from Naidu and others (1984) and serve as example.

Variation in coastal-plain composition (sediment grain size) is one of the main controlling parameters for coastal retreat rates. Coastal-plain deposits containing pebbles and cobbles in a sandy matrix erode much slower than those composed mostly of silt and clay, which also contain more ice (Hopkins and Hartz, 1978). Areas with fine-grained, coastal-plain deposits are also marked by a lack of protective beaches (fig. 5), due to the scarcity of sand and gravel-size particles. The

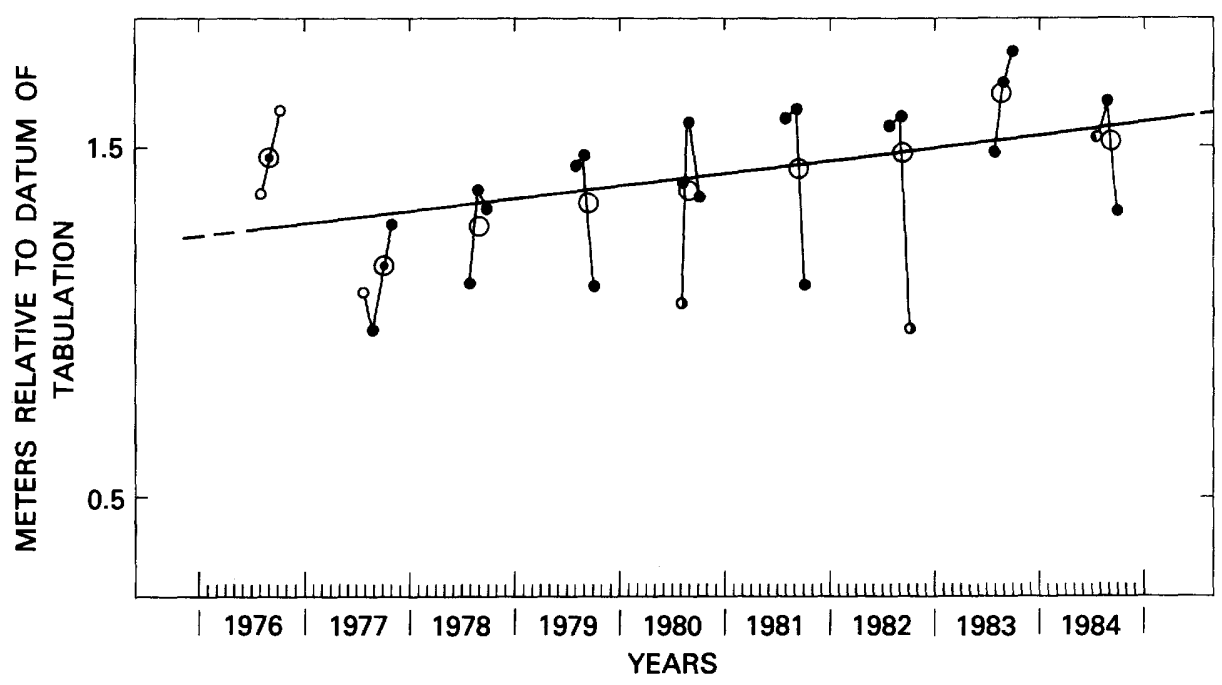

\section{EXPLANATION \\ Monthly mean \\ - $\quad<1 / 2$ month's data \\ - $1 / 2$ month's data \\ - full month's data \\ S Seasonal mean}

FIGURE 24.-Monthly (July, August, and September) mean and seasonal mean sea level measured at Prudhoe Bay West Dock - NOAA tide station \#949-7649. Trend line represents least square fit to seasonal mean data. Note sea level usually peaks in August (spring melt) and decreases thereafter (modified from D.L. Inman, written commun., 1984). 
dramatic differences in coastal retreat rates between the eastern and western parts of the study area are largely due to regional differences in sediment grain size. From Oliktok Point eastward the coastal plain is composed of a series of coalescing alluvial and glacial outwash fans extending $150 \mathrm{~km}$ northward from the Brooks Range (Hopkins and Hartz, 1978). Retreat rates for the coastline here are one-fourth of rates (1.3 versus $5.4 \mathrm{~m} / \mathrm{yr}$ ) between Cape Halkett and Drew Point, where the coastal plain is composed of marine mud (Carter and Robinson, 1981). The coarse Pelukian beach deposits north of Kogru River (sector 7) and possibly also exposed to the east in the form of high tundra-covered coastal-plain remnants of the Jones Island chain (figs. 18 and 20) (Hopkins and Hartz, 1978) are more resistant to erosion and control coastline evolution. Thus, the rapidly retreating promontory between Cape Halkett and Drew Point will likely stabilize in a few thousand years at the Pelukian barrier chain on the north shore of Teshekpuk Lake (fig. 25).

Degree and direction of exposure to the various climatic and oceanographic processes affects erosion rates. Open-water conditions with waves and currents are needed to remove the materials introduced by bluff erosion. Simpson Lagoon is ice free for a greater part of the summer than the "open-ocean" waters north of the Jones Islands (see typical ice distribution in fig. 19). The increased fetch in lagoons affords greater potential for erosive processes and consequently retreat rates in the lee of these islands are commonly higher than on the ocean-facing side (sector 15). Water temperature also affects erosion rates. Thus, the coastal-plain remnants in that part of the Jones Islands chain equidistant from the warming effects of the Colville and Kuparuk Rivers may be evidence of this influence. Such old remnants may have long since disappeared in the islands directly off the Kuparuk River, leaving barriers composed only of sand and gravel lag atop residual tundra cores. Cannon and Rawlinson (1981) pointed out that south-facing bluffs, those exposed to the sun for the greater part of the day, erode faster than north-facing bluffs. An example of the results of this difference in orientation is partly reflected in the higher erosion rate of bluffs on the south side of Pingok Island. Reimnitz and Maurer (1979) pointed out that storm surges, and therefore westerly winds in general, should be those most effective in producing significantly elevated tide and wave conditions, and thought that for this reason westfacing promontories retreat faster than those facing east. The resulting pattern, as best exemplified by the coastal configuration and retreat rates in sectors 13 and 14 , is indicative of processes acting in a direction contrary to those responsible for the westward orientation of the small coastal spits trailing off the mainland promontories. This pattern, however, does not occur elsewhere in the study area.

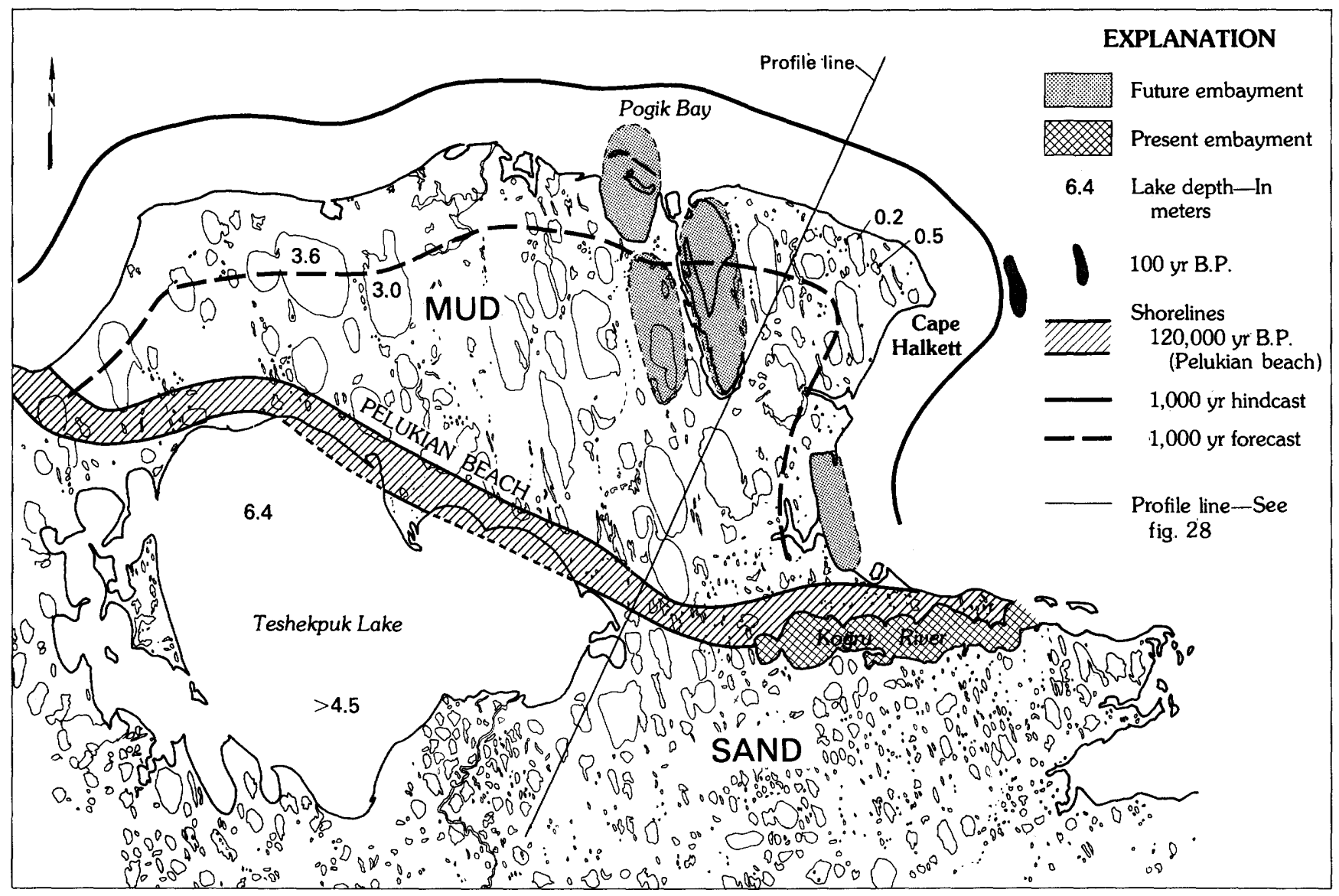

FIGURE 25. - Cape Halkett promontory showing Pelukian barrier chain 1,000-yr hindcast and forecast shorelines, reported lake depths, and an early 19th-century island off the cape. Largest shallow lakes, which may be candidates for model lagoon evolution (Wiseman and others, 1973), are shaded to show their distinction from present lagoons or bays. 


\section{FORMATION OF EMBAYMENTS AND LAGOONS BY THERMAL COLLAPSE}

Wiseman and others (1973) showed how thermal collapse of lakes breached by the transgressing sea results in embayments and lagoons (fig. 26). They envisioned a 4-phase evolution beginning with an area of large lakes similar to the Cape Halkett region. The coalescence of such lakes and the breaching and inundation by marine waters to form Kogru River-type inlets is their second phase. This is followed by a widening of inlets as phase 3, and eventual stranding of coastal plain remnants to form an island-protected lagoon setting similar to that of Simpson Lagoon. The scenario is concluded in phase 4 with the citing of Leffingwell Lagoon $(100 \mathrm{~km}$ east of study area) as an example of maturity where further erosion has reduced the island chain to a string of coarse lag barriers. Reimnitz and Maurer (1979) have pointed out problems with this model, presenting Kogru River and Prudhoe Bay as examples. The lakes in these two regions are currently perched several meters above sea-level. Thus, the anticipated thermal collapse of existing lake beds, without subsequent deepening

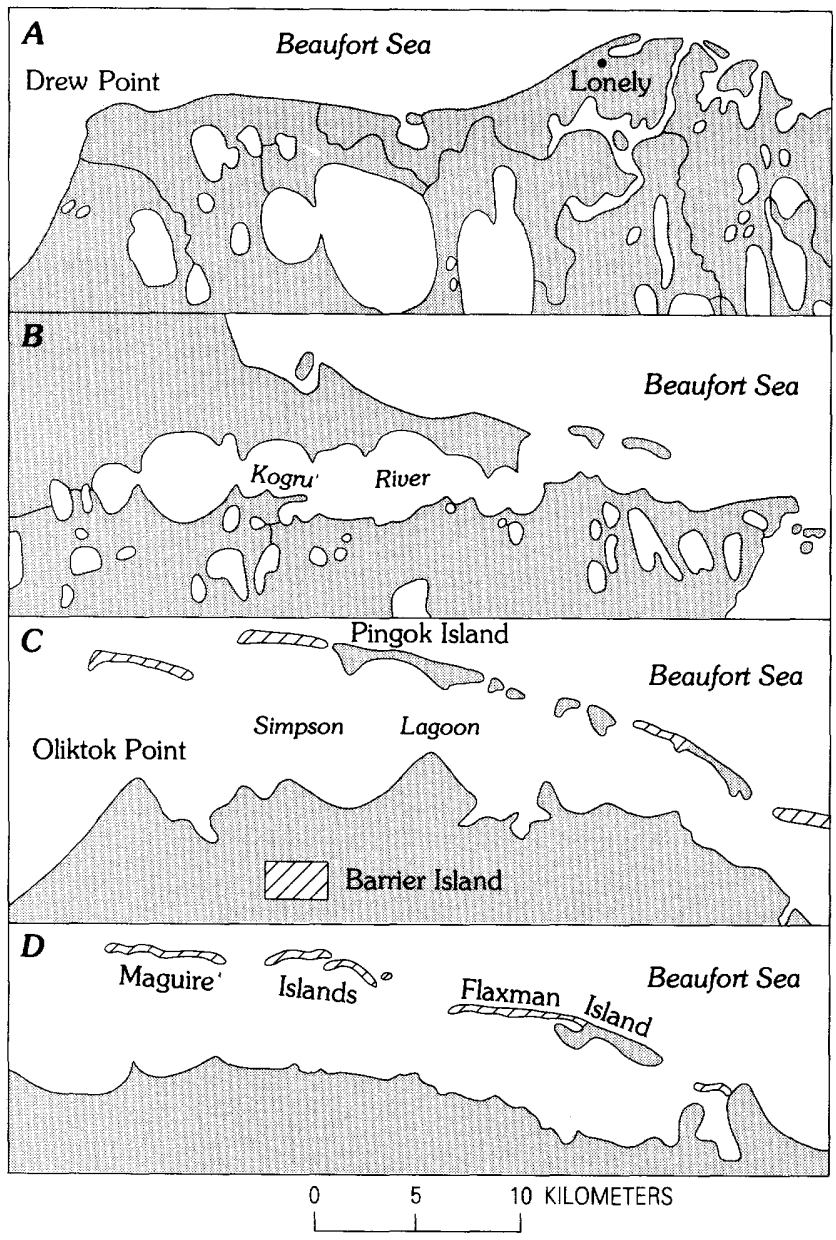

FIGURE 26.-Sequence of lagoon formation and barrier island isolation by thaw-lake coalescence. $A$, Initial tapping, draining, and coalescing of lakes, $B$, Continued coalescing of lakes and thermal erosion of shoreline, $C$, Continued thermal erosion and isolation of offshore tundra remnants, $D$, Erosion of tundra remnants and reworking of sand and gravel into offshore barriers (from Wiseman and others, 1973). by erosion, could not create the 3- to 4-m water depths found in these two embayments. Also, enlarging the types of lakes found north of Teshekpuk Lake (fig. 25) as in phase 2 of Wiseman and others (1973) would result in water bodies oriented at right angles to the existing major embayments and lagoons.

The lakes deeper than $2 \mathrm{~m}$ in the area north of Teshekpuk can be recognized by their persisting seasonal ice cover (fig. 20) (Sellmann and others, 1975). Actual lake depths according to Holmquist (1978), Charles Sloan (USGS, oral commun., 1980) and Jim Helmericks (bush pilot, oral commun., 1984) are shown (fig. 25). Three of the lakes have recently been breached by the advancing sea to form very shallow northwest oriented embayments. Pogik Bay is one such embayment. The 2-m isobath, perhaps marking the northern part of this former lake basin, juts seaward by about a kilometer from the general trend of that isobath on either side (see sector 4). Thus, the lake basin is a submerged promontory, more resistant to erosion than the surrounding terrain. Perhaps this can be attributed to the former existence of a deep lake underlain by a thaw bulb lacking excess ice. Upon breaching and inundation, such a lake bed would be dense and stable, and therefore not subject to further thermal collapse. A similar setting and evolution is described by Tomirdiaro (1975) for a cape in the East Siberian Sea, where the cape marks a deep lake basin breached by the transgressing sea. However, in 1985, we attempted to enter Pogik Bay by skiff, but were stopped by less than $30-\mathrm{cm}$ depth a kilometer into the entrance, and over much of the inner bay it is generally too shallow for use by even small float planes. The resistance to erosion here may alternatively be due to a thick accumulation of fibrous organic matter on the former lake bed.

The northeast coast of present Cape Halkett may define the west shore of a former large lake breached about 200 years ago. According to Leffingwell (1919, p.170), Dease and Simpson in 1837 mention a passage inside of a tundra-covered island which they named as the original Cape Halkett. Some 19 th century charts (for example H.O. chart no. 68, 1893 edition) show this island elongated parallel to the regional trend of lake axes. We have defined the approximate outline of this island (fig. 25). The last tundra remnants of the island disappeared by about 1945, and in 1952 it was charted as a shoal (sheet 7991). The water depth over the former lake between the cape and the shoal is now less than $2 \mathrm{~m}$.

These considerations lead us to conclude that the model of Wiseman and others (1973) for the formation of embayments and lagoons by thermal collapse is oversimplified, if not wrong.

\section{THERMAL COLLAPSE RESULTING IN THE DEVELOPMENT OF COASTAL SEDIMENT SINKS}

According to our tabulations, the sediment contribution from erosion in the offshore is slightly larger than that from the onshore. But the reliability of calculated values for this contribution is questionable due to the possibility of thermal collapse in the offshore zone. Harper (1978) in fact stated that "thaw subsidence causes a continual steepening of the offshore profile and provides a sediment sink for eroded sediments." In the following section, we analyze the Russian studies from the Laptev and East Siberian Seas commonly 
referred to in western literature (for example, National Research Council, Marine Board, 1982) and then an example profile from our study area for evidence on thermal collapse.

\section{Example from the East Siberian Sea}

Russian workers have attributed the most important role in shaping of arctic continental shelf profiles to thermal energy and related processes. Thus, Tomirdiaro (1975) states "The eastern Arctic seas are largely young Holocene bodies of water formed by thermo-abrasional processes; it is thermo-abrasion, and not the usual abrasion processes, that has formed the so called Arctic continental-oceanic zone here in such a short time." His interpretation relies heavily on marine studies reported on by Klyuyev (1965). The data Klyuyev presents are hydrographic surveys repeated over time intervals of 15 to 20 years, off coasts that are retreating as fast as the coast in sectors 1 through 6 in our study area. One of these surveys repeated after 15 years (fig. 27) suggests a maximum lowering of the sea floor by 0.6 to $0.7 \mathrm{~m}$ in the depth range of 2 to 4 $\mathrm{m}$, or a shoreward shift of the 2-, 4-, and 6-m isobaths by 0.5 to $1.2 \mathrm{~km}$. The sea-floor lowering was less pronounced adjacent to the coast, and on the outer end of the profile at 6- to $7-m$ water depth. Klyuyev claims that the possibility of errors in navigation or in sea-level datum were definitely excluded in these surveys. We note that the $0-\mathrm{m}$ isobath, which should represent the shoreline, remains stationary, according to his interpretation, while the bluff retreated by $170 \mathrm{~m}$. The implied type of landform development seems highly unlikely and detracts from the credibility of his interpretation.

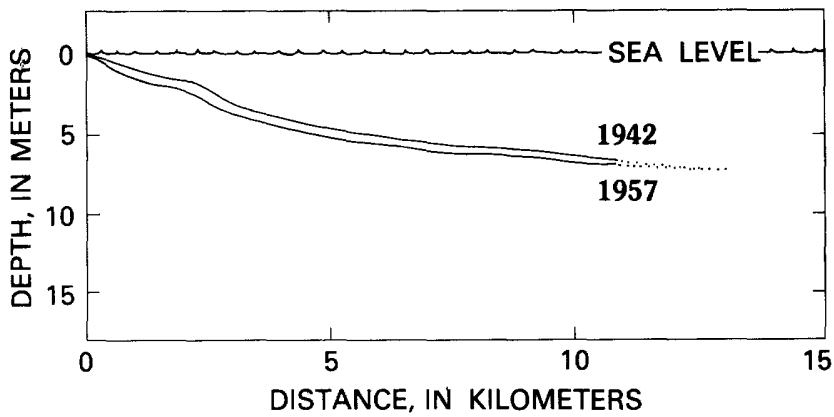

FIGURE 27.-Two depth profiles from the East Siberian Sea, resurveyed at right angles to, coast after 15-yr time interval, showing presumed thaw settlement (after Klyuyev, 1965.)

Klyuyev (1965) apparently attributes the depth changes entirely to thermal collapse, and presents evidence that the upper surface of the ice-bonded section is at or immediately below the sea floor. The evidence he presents may also be interpreted differently. He reports that short cores may contain several millimeter-long ice crystals. We have observed that small ice crystals form in fine-grained sediments during fall storms, when ice formation is triggered by a rise in water salinity and a drop in water temperature to slightly below the freezing point. The sediment interstitial water often retains a slightly lower salinity acquired during summer river discharge onto the shelf. The ice platelets seem to decay within a month after winter has begun, and, therefore, are a seasonal component of surface sediments. He also reports ice within the sediments and ice-bonded sediments in areas normally submerged, but exposed during strong winds. Ice-bonded sediments in the Alaskan Arctic are also near the surface in such shallow areas, where the fast ice rests on the bottom at winter's end. The thinness of the unbonded sediment layer in such shallow water, however, is not an indicator of the thinness of unbonded sediments offshore. He further cites as indirect confirmation of the existence of permafrost on the sea floor: "Vessels drift during a storm even with two anchors. The anchors slip over the solid bottom, and when the depth is slight a characteristic knocking can be heard." The bottom is not rocky where these observations were made. Such observations have also been made during fall storms in the Alaskan Arctic, where during summers sediments are soft and present no anchoring problems (Jim Adams, tug boat operator, oral commun., 1984). Our work has shown that shallow-water sand and coarser deposits during freeze-up storms not only become ice bonded, but form anchor ice, as discussed earlier. This seasonal ice bonding can explain the above observations made by captains of vessels in the Arctic. Ice bonding, however, apparently forms only a surficial crust, which disappears soon after the ocean has formed a new ice canopy. The annual formation of an icy crust on the sea floor can not result in net thermal collapse. The principal evidence for submarine thermal settlement brought forth by Klyuyev is the presence within the Laptev and East Siberian Seas of wedge-shaped depressions with peaked flanking ridges, which he interprets to be thermokarst features, resulting mainly from the melting of submerged ice wedges. These are subdued in shallow waters, become best defined with increasing water depth (15 to $20 \mathrm{~m}$ ), and are found seaward to $50-\mathrm{m}$ depth. This distribution pattern, with better preservation at increased water depth where sediments should become finer and more cohesive than on the inner shelf, and also the shapes of the features on fathograms, match exactly the sediment and ice gouge pattern on the Beaufort Sea shelf (Reimnitz and Barnes, 1974; Barnes and others, 1984). The features reported by Klyuyev are much too large (120-m wide) to be produced by melting of ice wedges. ${ }^{3}$ Lastly we note that thaw settlement in the coastal zone of the Laptev and East Siberian Seas should result in the trapping of most sediments introduced. There should be little chance for sediment sorting, and the underlying ice-bonded materials should become buried by sedimentary accumulations. Yet, the local bluffs introduce silt and clay-size materials, while offshore deposits are sandy. To us, this indicates that a significant amount of mechanical, rather than purely thermal energy, is at work winnowing the sediments introduced. The steep-sided depressions with their jagged flanking ridges are very short-lived in the Beaufort Sea, and we believe that overall the sedimentary environment is not very different from that of the Laptev and East Siberian Seas.

\section{Analysis of a North Slope profile}

The following is an analysis of a coastal-plain and continental-shelf profile in the most dynamic region of our study area near Cape Halkett and will shed further light on the

\footnotetext{
${ }^{3}$ There is a large discrepancy between the 8- and even $12-\mathrm{m}$ depression depth Klyuyev quotes and the maximum 5-m depression depth we measure from his figures.
} 
question of thermal collapse. The overall profile compiled from published topographic maps and charts is shown (fig. 28). The line trending northeast (fig. 25) indicates the precise location of the profile. This particular line was chosen as the onshore continuation of an offshore profile, which we have surveyed repeatedly from 1977 through 1980 in our monitoring of the rates of ice gouging.

The coastal plain from the beach to a distance of $35 \mathrm{~km}$ inland has slightly undulating relief ranging between 5 and 12 $\mathrm{m}$ above sea level. The first $5 \mathrm{~km}$ from the beach are marked by generally increasing elevations, with a slope that matches that of the sea floor out to a few kilometers onto the continental shelf. The coastal zone is a pronounced niche in this profile, as amplified in figures $28 B, 29 A$ and $B$, and 30 .

The inshore part of our survey lines lies near the baseline connecting the two shore stations used for navigational control. This geometry results in the introduction of possible north-south positioning errors of at least $23 \mathrm{~m}$. The westem shore station is located at the corner of the hut at Esook (fig. 5), which has not been surveyed accurately. Thus, there is an additional unknown error that affects the comparison between the 1950 and 1980 profiles. Our fathograms show slight, local depth differences from one season to another during the 1977 to 1980 interval, but in view of the possible position errors, the overall bottom profiles are similar enough to be shown as a single solid line (fig. 28B). This line is relative to a sealevel average for all survey periods, and has a likely error of $20 \mathrm{~cm}$ relative to the true datum. Our surveys stop at the bar marking the seaward edge of the $2-\mathrm{m}$ bench; the missing part of the profile from there to the beach is shown as a straight line, the dotted line (fig. 28B) is taken from a dense set of soundings made by the C\&GS in 1952.

The 30-year comparison of the inner shelf bottom profile (fig. $28 B$ ) suggests a slight buildup $(5-20 \mathrm{~cm})$ at a distance of 5 to $10 \mathrm{~km}$ from the coast, and deepening $(10 \mathrm{~cm})$ in the first kilometer seaward of the 2-m bench. This comparison also suggests that the seaward edge of the 2-m bench maintained its position, while the coastline retreated. This is in conflict with the model we use for calculating sediment input by erosion. We have no data on any depth changes across the 2-m bench, from where according to our methods and calculations the major part of the sediment budget is derived. The suggested widening of the $2-\mathrm{m}$ bench at this site during the past 30 years should be verified by increased accuracy of bathymetric surveys. Meanwhile, an analysis of the offshore extension of the profile in light of the extremely rapid transgression is informative.

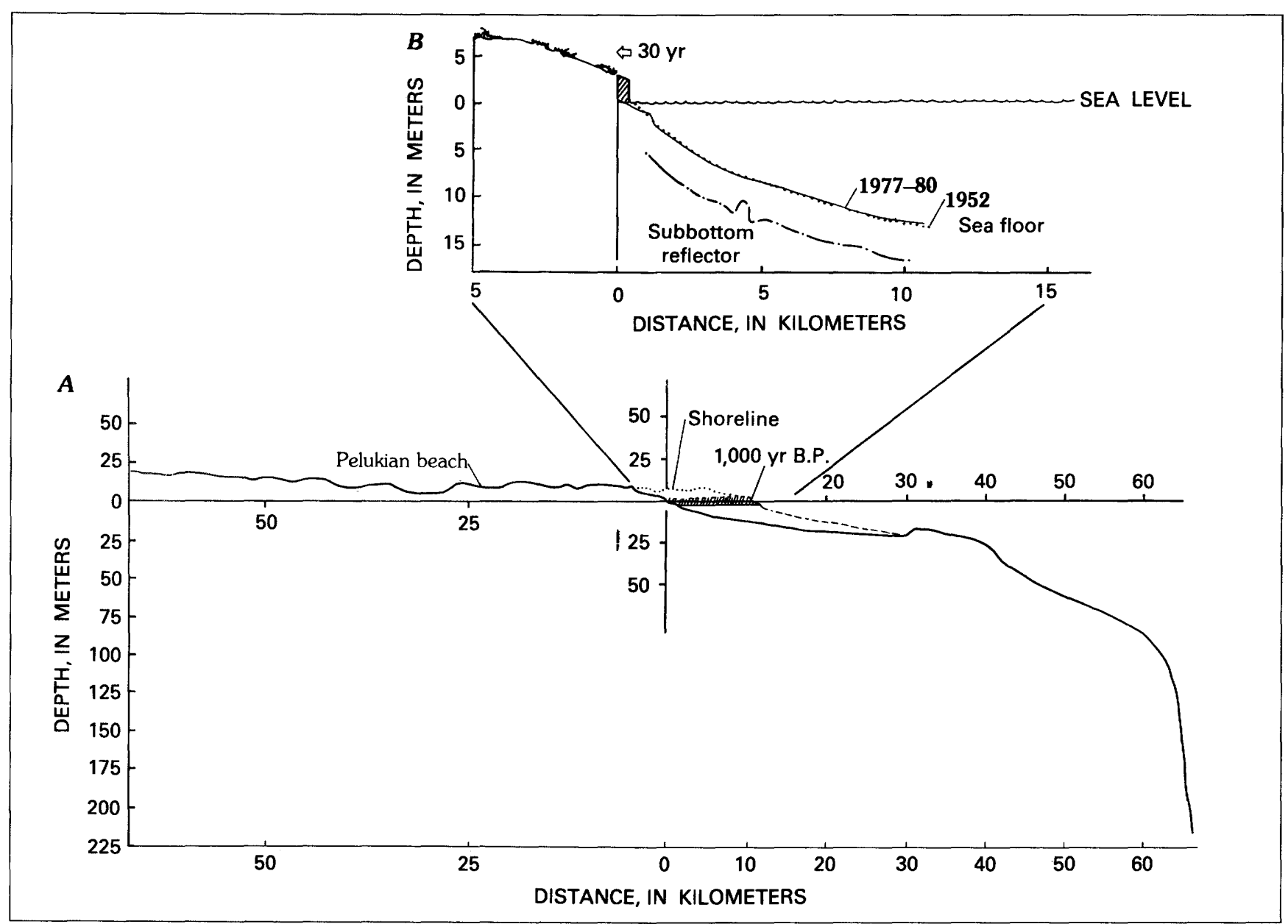

FIGURE 28-Coastal-plain/shelf profile along line indicated on figure 25. A, Present profile and 1,000-yr hindcast with accounted (lined area) and unaccounted volumes indicated. B, Detailed coastal-zone profile showing 30-year comparison of bluff and sea floor (1952 versus $1977-80)$ and shallow seismic reflector. 


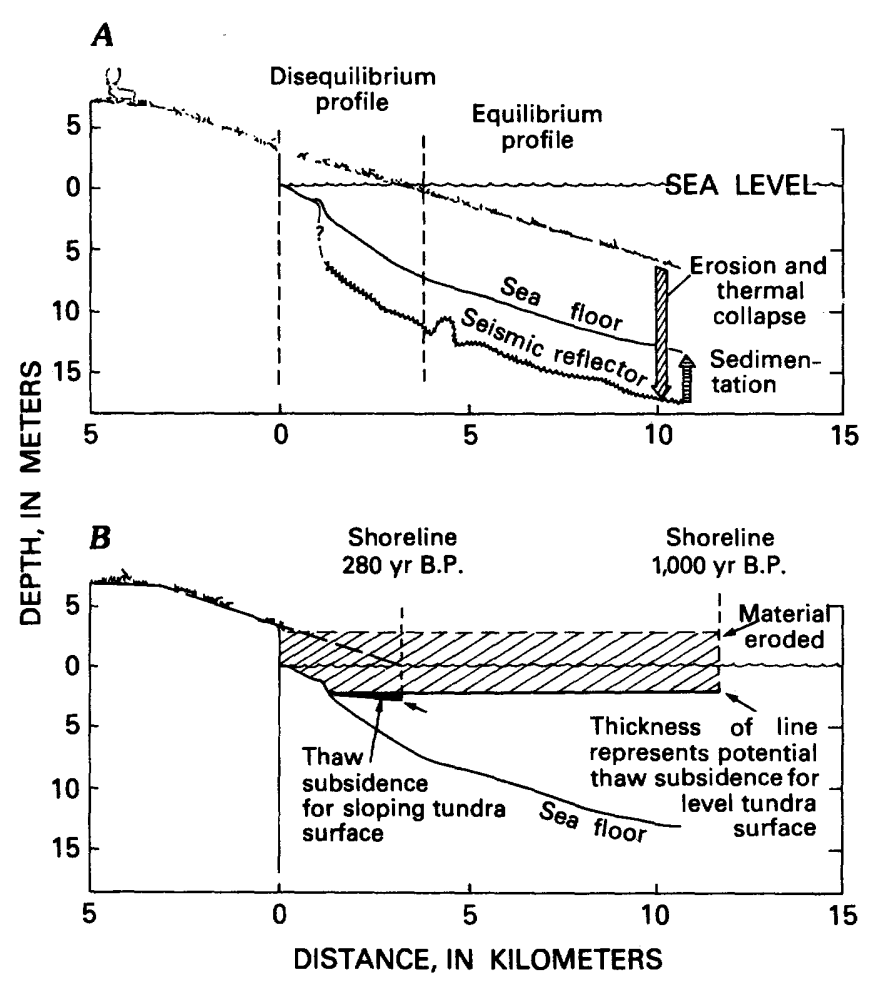

FIGURE 29. - Same profile as figure 28B showing hypothetical tundra surface. $A$, Possible origin of seismic reflector as old land surface after erosion, thaw subsidence, and Holocene sedimentation. $B$, Potential thaw settlement below minus 2-m truncation surface for both level and sloping tundra surfaces assuming deep thaw.
The shallowest seismic subbottom reflector below the shelf surface, as delineated by a $7-\mathrm{kHz}$ profiling system used in conjunction with the depth recorder is shown (fig. $28 B$ ) and this reflector characterized by jagged relief of 2- to 3-m amplitude is indicated schematically. This reflector is smooth only across a 2-m-high, 500-m-wide, mound at $2.5 \mathrm{~m}$ below the present sea floor, located $4.5 \mathrm{~km}$ from the coast.

In our Beaufort Sea geophysical studies, we have generally taken the shallowest, continuous, subbottom reflector to represent the base of Holocene marine sediments, for reasons discussed by Reimnitz and others (1982). In numerous instances, this interpretation has been confirmed by coring and other field studies. In the area of Cape Halkett however, we have no such ground truth. If we assume this reflector is the base of the Holocene sediments as elsewhere, then it may mark the former land surface, having been slightly modified by the beveling action of the transgressing sea, which reworks just the upper few meters of coastal-plain deposits. As the transgression proceeds, material below sea level may for a time experience additional thaw collapse, and this may explain the different slope of the inshore $5 \mathrm{~km}$ of sea floor and subbottom reflector. As thaw settlement is completed and all material reaches equilibrium with the thermal regime, the slope of the sea floor flattens out at an attitude parallel to the slope of the old tundra surface. Following this line of reasoning the vertical distance separating the trace of the old tundra surface beveled to sea level and the position of the first subbottom reflector may be explained by $8 \mathrm{~m}$ of erosion and thaw settlement, which is then followed by redeposition of as much as $4 \mathrm{~m}$ of bluff and nearshore material. This hypothesis is illustrated in figure $29 \mathrm{~A}$ and is shown to be unlikely in the following sections.

The jagged subbottom reflector is characteristic of several extensive regions in the Beaufort Sea. In one such area, industry soil borings showed the reflector to conform to the top of ice-bonded sediments. At two sites several kilometers

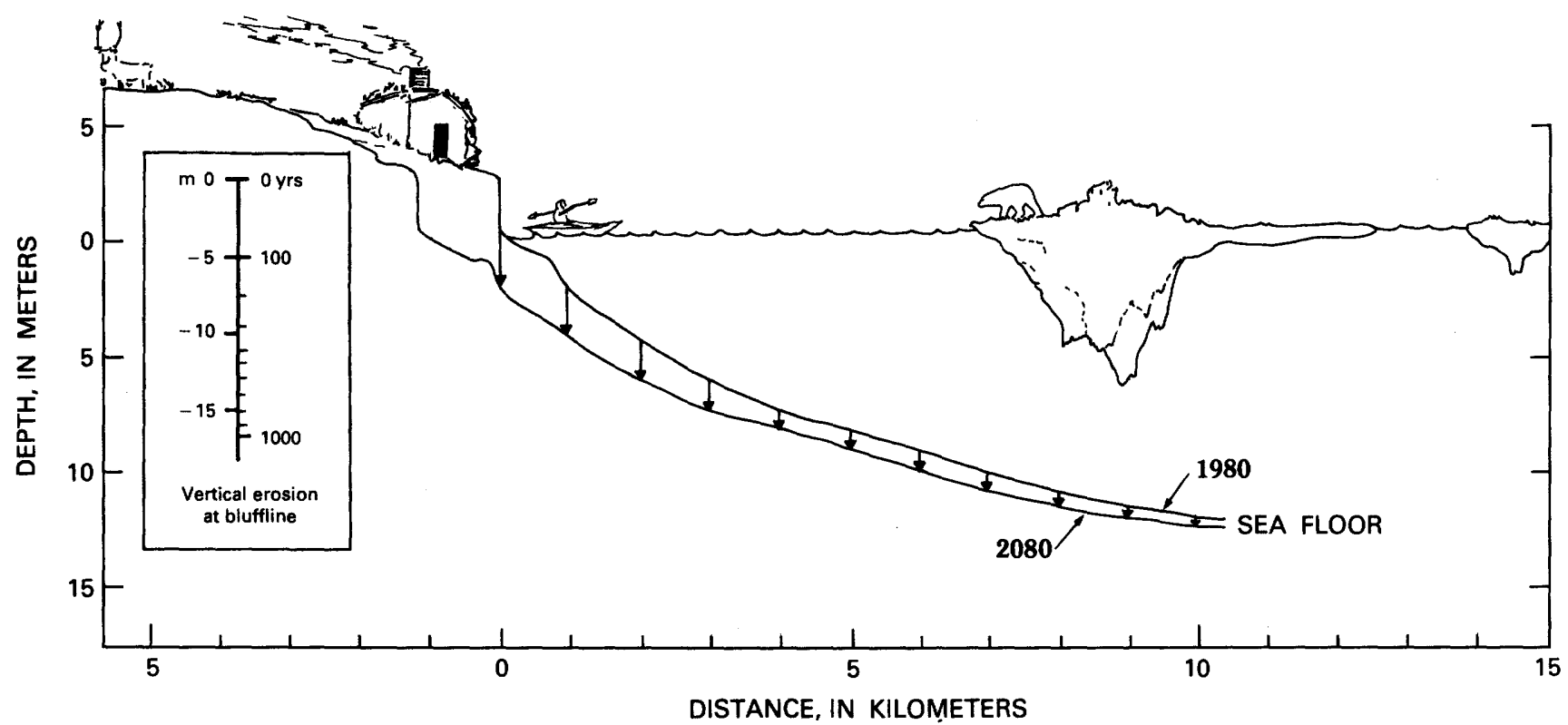

FIGURE 30.-Present land and sea-floor surface with arrow lengths indicating vertical erosion predicted for next 100 years at 1-km intervals along profile; inset shows 1,000-yr vertical erosion predicted for a point at present shore. 
west of our profile, Harrison and Osterkamp (1981) investigated the depth to ice-bonded permafrost. At $2.7-\mathrm{m}$ and at $5.5-\mathrm{m}$ water depth, the first ice was penetrated 4 and $5 \mathrm{~m}$, respectively, below the sea floor. At the latter hole, the phase change from partial to solid bonding was found between 5 and $7 \mathrm{~m}$. T.E. Osterkamp (oral commun., 1984) believes that the boundary from which seismic energy is reflected should be very irregular under these conditions. Alternatively, and to us more likely, the subbottom reflector (figs. $28 B$ and $29 A$ ) therefore may mark the upper surface of bonded subsea permafrost. From the point near shore, where the reflector terminates on our records, it probably rises beneath the $2-\mathrm{m}$ bench, to conform to the sea floor from there to the beach, and then up to the land surface. If so, this reflector can not also be the former coastal-plain surface, or interface between older and Holocene sediments.

The inner shelf profile is shown (fig. $28 \mathrm{~A}$ ) where it would have been 1,000 years before the present, assuming the maintenance of a profile of dynamic equilibrium. Even if the sea-floor slope was much steeper at that time, this reconstruction implies a large wedge of material is unaccounted for in our calculations of sediment removed during transgression. Our tabulations account only for the hachured portion of this cross section. We indicate (fig. 29B) how much of the implied missing wedge can be reasonably attributed to thaw settlement. We again use data from Sellmann and others (1975), and assume that sediments in situ retain a porosity of about 40 percent after thaw collapse. Sellmann's data from the Barrow area indicates that most excess ice, and therefore thaw settlement, occurs in the upper $7 \mathrm{~m}$ of coastal plain. We apply that data to two hypothetical cases, where both assume a constant sea level. In the first case, the coastal plain extended seaward horizontally at a level $3 \mathrm{~m}$ above the present sea, and was removed to the minus $2-\mathrm{m}$ level by erosion and deposited elsewhere. The thickness of the line at the base of this eroded slab represents the amount of thaw settlement possible for that erosion surface (about $5 \mathrm{~cm}$ ). In the second case, the old tundra surface was sloping to intersect sea level $3 \mathrm{~km}$ from the present shore, and again was truncated down to the minus 2-m level. We can only make reasonable estimates of thaw settlement for this erosional surface from the edge of the 2-m bench to the point where the coastal plain dipped below sea level. The possible thaw settlement is indicated as a wedge, with a maximum thickness of $39 \mathrm{~cm}$ at a point where todays water depth is $7.5 \mathrm{~m}$. At this point, the discrepancy between the eroded slab we account for in our sediment yield calculations plus thaw settlement on one hand, and the actual sea-floor profile on the other hand, is about $5 \mathrm{~m}$. Using available data, the maximum thaw settlement that could have occurred anywhere along this profile is only $1.5 \mathrm{~m}$.

Although we do not know the distribution of excess ice in the offshore, our analysis of the profile strongly suggests that the niche in the coastal zone must be due to either (a) erosion and lateral transport of sediment through a combination of processes involving ice, waves and currents; or (b) was produced over a long time period as the result of processes acting in a somehow different setting, in which the position of the coastline remained stable. Analyses of temperature profiles in 5 boreholes offshore from Pitt Point (sector 2) indicate a sustained retreat rate of several meters per year for the past 1,000 years (Harrison and Osterkamp, 1981). Further- more, Lachenbruch (1985) states "the absence of a thermal disturbance in coastal wells along the Beaufort Sea implies the shoreline has been transgressing rapidly'. Thus we rule out the possibility that the shaping of the shelf profile occurred over a long time span marked by coastal stability, and that the present rapid coastal retreat was triggered only recently.

The transgression is rapid along the entire Beaufort Sea coast from Barrow to the Mackenzie River delta in Canada (Hopkins and Hartz, 1978). The profile discussed above is not unusual for this coast, except for the areas off the two largest rivers, the Colville and Mackenzie. The bluff retreat is not associated with the formation of a platform near sea level. This implies that the entire inner shelf is an erosional surface, where possibly several tens of meters have been removed since the beginning of the present transgression.

There is indeed strong evidence that much of the Beaufort Sea inner shelf is an erosional surface. Reimnitz and others (1982) showed a sparsity of Holocene marine sediments for the region between long $146^{\circ} \mathrm{W}$. and the Canadian border, and presented seismic evidence indicating that the inner- and midshelf surface truncates older strata. Isopach maps of Holocene sediments prepared since show that such materials are restricted to bays and lagoons in that region. Similarly, the inner shelf surface between long $146^{\circ} \mathrm{W}$. and the present study area, from the island chains to about $30-\mathrm{m}$ water depth, truncates older seaward-dipping strata (Wolf and others, 1985). These findings are supported by studies of over 20 boreholes in that area (Smith, 1985). Overconsolidated silt and clay deposits cover are widespread over the Alaskan Beaufort Sea shelf. Lee and others (1985) have studied the physical properties and consolidation mechanisms for surficial sediments in the Prudhoe Bay area and conclude that subaerial freezing during periods of lower sea level is probably the principal cause of overconsolidation. This implies that sediments of this type on the modern sea floor are older than the present sedimentologic regime, and may be uncovered by ongoing erosion. Only the lagoons contain accumulations of soft Holocene marine sediments, which we will show to be only temporary deposits. Analysis of seismic records in the present study area has not yet been completed, but the data at hand indicate a similar setting.

\section{VERTICAL SHELF EROSION BY A SHIFTING "EQUILIBRIUM PROFILE"}

In seas not dominated by ice, the inner shelf apparently maintains a profile of dynamic equilibrium, a concept referred to by some as "Bruun's Rule" (Bruun, 1962; Schwartz, 1967; Swift, 1968; and Rosen, 1978a, b). Winant and others (1975) show that seasonal changes in the profile across the beach and out to $10-\mathrm{m}$ water depth can be described using empirical eigenfunctions. While the year round presence of drifting pack-ice strongly affects processes, and very likely also the shape of the profile, we can nevertheless assume that the profile is maintained and shifted landward as the sea transgresses. Let us consider the implications of a dynamic equilibrium profile through the last thousand years for the Cape Halkett area.

Sea level likely was constant while the coast retreated about $10 \mathrm{~km}$ (fig. 28A). This reconstruction has two important implications: (1) the amount of sediment supplied to the sea by erosion is increased by at least a factor of four over that 
calculated from bluff and shallow nearshore erosion alone, and (2) we can calculate vertical erosion rates (fig. 30) for any point on the inner shelf profile. The length of arrows along the profile indicate the depth to which erosion would lower specific points on the sea floor during the next 100 years by a simple landward shift of our assumed "equilibrium profile". The scale to the left of the profile shows the expected vertical erosion versus time anticipated for a point originating on the tundra surface. While the length of arrows along the profile will not serve as actual measures of sea floor erosion to be expected by designers of buried pipelines, they must be considered in the development of offshore North Slope oil fields. Dunton and others (1982) presented supporting evidence for modern vertical erosion at 6-m depths in the sheltered waters of Stefansson Sound, directly off the mouth of the Sagavanirktok River $15 \mathrm{~km}$ east of the study area. This ongoing erosion resulted in the formation of the Boulder Patch, a modern, boulder, lag deposit in Stefansson Sound.

\section{TOTAL SEDIMENT YIELD FROM RIVERS AND COASTAL EROSION}

To obtain the sediment yield for that portion of the North Slope feeding the shelf within our study area, we must first evaluate what is known about the river input to the sea. Milliman and Meade (1983), using 5.8 million tons as the annual suspended sediment load of the Colville River (Arnborg and others, 1967), with a drainage basin of $50,000 \mathrm{~km}^{2}$, estimate northern Alaska's sediment supply from rivers at 120 ton $/ \mathrm{km}^{2} / \mathrm{yr}$. For the following reasons we believe that number is an order of magnitude too high: Vast regions in the Eurasian Arctic with settings similar to that of the Colville River drainage area yield $8 \mathrm{ton} / \mathrm{km}^{2} / \mathrm{yr}$ according to the compilations by Milliman and Meade (1983). They use that same number as an estimate for northeastern Canada. The Mackenzie River drainage basin yields only 55 ton $/ \mathrm{km}^{2} / \mathrm{yr}$ into the Beaufort Sea (Milliman and Meade, 1983). The Babbage River (between the Mackenzie River and the Alaska-Canada border) according to two years of measurements by Forbes (1981) yields 42 ton $/ \mathrm{km}^{2} / \mathrm{yr}$. The yield for these two rivers should be much higher than that of the flat Colville River drainage area. The Sagavanirktok River immediately east of our study area (draining $14,500 \mathrm{~km}^{2}$ ) according to our own sketchy measurements yields about 5 ton $/ \mathrm{km}^{2} / \mathrm{yr}$, and according to one summer of stream gauging by Northern Technical Services yields 7.4 ton $/ \mathrm{km}^{2} / \mathrm{yr}$ (R.P. Britch, written commun., 1984). Even the Sagavanirktok River, judging by its steeper gradient and braided nature, should have a higher sediment yield per unit area than the Colville River.

In view of the above considerations, we give an estimate of $10 \mathrm{ton} / \mathrm{km}^{2} / \mathrm{yr}$ as the sediment yield from $74,000 \mathrm{~km}^{2}$ drainage areas adjoining the coastal sector studied here (fig. 1). Upland sources accordingly yield 740,000 tons of sediment per year. This compares to about 5 million tons per year contributed by coastal erosion. Previous studies estimated that streams supply four times more sediment to the Beaufort Sea than coastal erosion (Owens and others, 1980). According to our own calculations the sediment yield from coastal erosion is seven times higher than that from streams, and we believe that factor is very conservative.

\section{INNER SHELF EROSION AS A MAJOR SEDIMENT CONTRIBUTOR}

Based on the geometry assumed in our study, the thickness of the sediment layer removed between the shoreline and the $2-\mathrm{m}$ isobath during the 30-year period of coastal retreat is typically less than $20 \mathrm{~cm}$. In reality the layer very likely is many times thicker and also extends seaward far beyond the $2-\mathrm{m}$ isobath. Thus, the sediment yield resulting from the erosive transgression is many times larger than we calculated. If, for example, the profile is in dynamic equilibrium to $10-\mathrm{m}$, rather than to 2-m depth, the sediment yield from offshore erosion is five times larger. Thus, the rate of coastal transgression is influenced not only by lithology of bluff materials, but by the lithology of sediments underlying the inner continental shelf. Some of these subsea deposits may find their way to the beaches through ice push and in turn affect beach lithologies.

The above considerations imply that a several-meter-thick blanket of Holocene marine sediments found locally on the actively eroding part of the profile represents sediment in a state of flux. Over large areas, this layer is about as thick as the maximum ice-gouge incision depth (Barnes and others, 1984) or roughly one tenth of the water depth out to the $40-\mathrm{m}$ isobath. Off deltas the layer is about as thick as the depth to which strudel scour (large craters scoured by vertical jet flow of river water draining through the ice during spring flooding) reworks the section or about $6 \mathrm{~m}$ (Reimnitz and Kempema, 1983). Such processes excavate older sediments underlying the shelf and mix them into the flux. The resulting layer may be viewed as a "roto-till", or "gouge-till" unit. These sea-ice related erosive processes explain why the surface sediments contain mixtures of modern foraminifers together with iron oxide stained, older forms that appear outside of their depth range and habitat (Kristin McDougall, oral commun., 1984). This process also explains why clay mineral suites in surface sediments, unlike other Alaska shelf regions, do not reveal patterns that can be traced back to their continental source regions. The distribution of suites instead is patchy and has been attributed to the relict nature of surface sediments (Naidu and Mowatt, 1983). Similarly, studies of quartz-grain surface textures show that the shelf-surface sediments are dominated by textures produced in eolian environments, different from grain surface textures on the coastal plain and in local river sediments (Hodel, 1985).

Given the sediment input from coastal erosion and streams, and published estimates of littoral transport in the Beaufort Sea, one is led to attempt completing the sediment budget by considering the sinks. Placing a sediment budget within the constraints of the concept of the littoral cell, including sources, pathways, and sinks (for example, Inman and Chamberlain, 1960; Inman and Brush, 1973) has proven useful in studies elsewhere. The concept requires a dominant source at one end, and a major sink somewhere off the other end of the cell. This concept seems to break down where the system is not dominated by point sources, as in our case. A rather even distribution of inputs from erosion of the Beaufort Sea coast far outweighs river input. Average littoral transport is capable of passing as much as 10,000 tons of material past a point along the shores of the Beaufort Sea (for example, Short and others, 1974). The average sediment input resulting from coastal retreat is 13,800 ton $/ \mathrm{km}$ of shoreline. As reported earlier, the above sea-level part of the coastal plain in the study area is 
composed of about 50 percent sand with less than 1 percent of gravel, the materials considered in littoral transport estimates. The implication is that the littoral transport system at almost any point along the coast will be choked with sand introduced by the erosion of only about $2 \mathrm{~km}$ of updrift shoreline. At such high input levels either sediment sinks are very closely spaced here, or transport mechanisms and agents other than those considered active in low latitudes environments must dominate in the Arctic nearshore.

A lack of sediment sinks on the exposed inner shelf and the restricted occurrence of Holocene sediments within the shelter of certain lagoons has already been discussed. Can the sediments collecting within the lagoons, and those contained within the islands chains, account for the sediment input to the Beaufort Sea over geologic time scales? Our study of Simpson Lagoon sheds some light on this question. Crude calculations comparing the present volume of the lagoon with its sediment supply indicate that the basin would fill to sea level within several hundred years. That obviously is not occurring, and therefore the lagoon over long time spans is not accommodating the sediment introduced, but is by-passing large amounts of material. The fact that the lagoon is being enlarged by erosion greatly complicates any attempts to predict even its immediate future. The development of Simpson Lagoon paleoshorelines during the past 5,000 yrs is shown from bluff retreat rates (fig. $31 B$ ), as interpreted by Naidu and others (1984). We noted previously that measurements of bluff retreat rates over short time periods are not expected to parallel shoreline retreat rates exactly, and in this case they do differ from our estimates. A present day profile of the area, together with hypothetical profiles 1,000 yrs ago, and predicted for the year 3,000, are shown (fig. 31A) based on the regional average erosion rate of $2 \mathrm{~m} / \mathrm{yr}$. This profile evolution is intended to depict 'a lagoon', rather than Simpson Lagoon specifically. The profile also shows the generalized upper surface of a thick underlying unit of massive gravel specific to Simpson Lagoon. We constructed this profile from 12 soil borings in the area.

The information contained in figure 31 leads to the following observations. Even during the past 5,000 yrs, since worldwide, sea-level rise reached its present position and the transgression ended elsewhere, it has continued at such a rapid rate in the Arctic that lagoons must be considered as ephemeral features only. Thus, even the modern deposits contained in Arctic lagoon and barrier-island systems can not serve as long-term sediment sinks. These deposits are in a state of flux, to be remobilized by the advancing sea within several thousand years. More importantly, the modern lagoon and barrier-island profile and deposits are only thin surficial features in the predicted deep-reaching profile evolution during a 2,000-yr time span. This particular profile seaward of the islands apparently has cut a deep notch into the underlying fluvial gravel.

Since even the outer shelf is presently an area of sediment by-passing (Reimnitz and others, 1984), the ultimate depository should be the Arctic basin floor. While deposition rates in the deep Arctic Ocean have in the past been thought to be very low, recent work by Sejrup and others (1984) suggests values many times higher.

Surficial sedimentary deposits of the coastal plain north of the Pelukian shoreline (fig. 25) are tentatively interpreted as

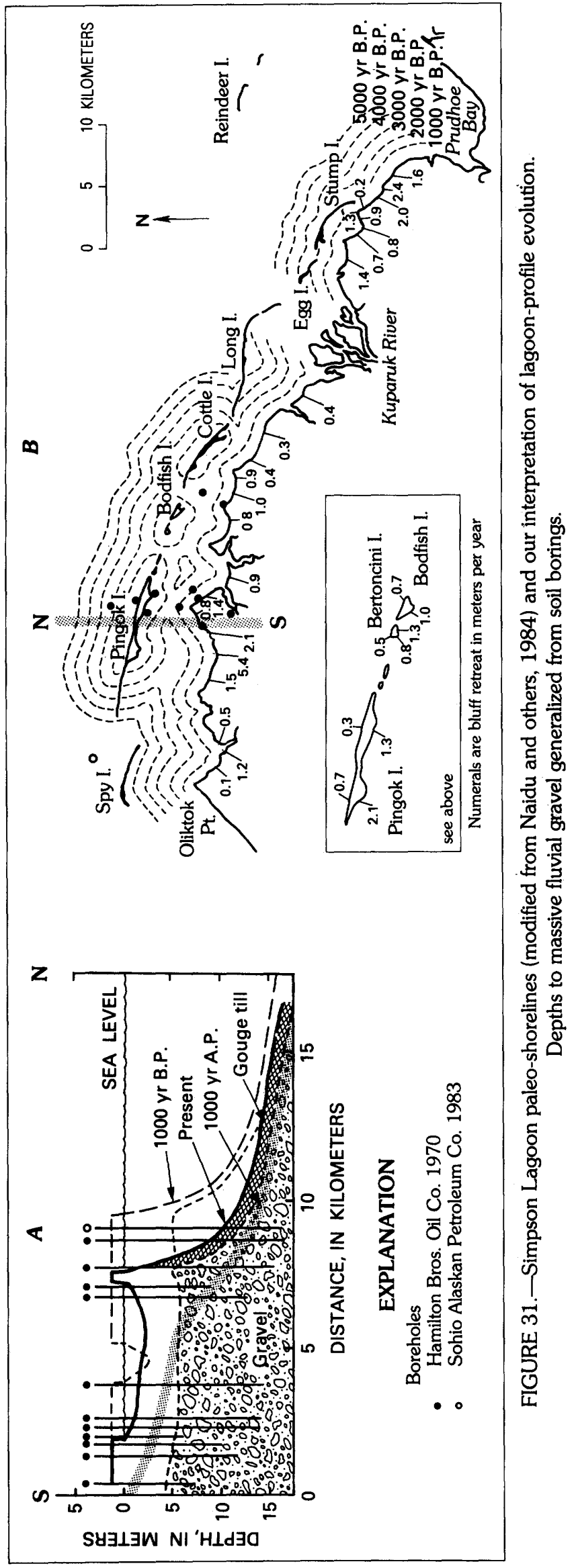


inner-shelf deposits from the last marine transgression (Carter and Robinson, 1981). Similar interglacial units as thick as 15 $m$ underlie much of the present inner shelf, where they are being truncated by the current transgression. Thus, the Holocene transgressive and erosional environment seems to contrast with depositional environments of past interglacial periods. One known difference between the last interglacial period and the present is that sea level was 7 to $8 \mathrm{~m}$ higher than now. We feel that higher water level alone cannot explain why marine sediments accreted in shallow water during past transgressions were preserved. There is, however, increasing evidence indicating that the last interglacial transgression had warmer air and sea temperatures than today. This implies there was less sea ice. Thus Hopkins and Carter (1980) state the "straightness of a $250-\mathrm{km}$-long barrier chain and presence of microfauna now endemic to the North Atlantic indicates that Pelukian deposits of northern Alaska formed at a time when the Beaufort Sea and channels between the Canadian Arctic islands were more open than now". Other studies of over 20 offshore boreholes also suggest that marine deposits of Pelukian age were not disrupted by ice gouging (Peggy Smith, oral commun., 1984). Conditions during the last transgression, when glaciomarine sediments of the Flaxman Member (of the Gubik Formation) were deposited, are less clear. Carter and others (1985) believe that the Flaxman deposits may originate from a time when enormous volumes of floating glacial ice were produced by the rapid break-up of a large part of the Laurentide ice sheet. The presence of much glacial ice and findings of fossil ribbon seal and gray whale very rarely found in the Beaufort Sea today might also indicate warmer conditions, and possibly again less sea-ice growth than at present.

\section{COMPARISON WITH GULF COAST EROSION RATES}

May and others (1983) compiled information on the erosion rates of continental U.S. shorelines. They state "the Gulf Coast States have the distinction of having the most rapid average erosion rates $(1.8 \mathrm{~m} / \mathrm{yr})$ on a national scale." The Texas coast is marked by lagoons bordering a flat coastal plain of poorly consolidated sediments and recent crustal stability. This coast, with a setting similar in many respects to that of the North Slope, erodes at an average rate of $1.2 \mathrm{~m} / \mathrm{yr}$. The Beaufort Sea coast retreats at a rate almost twice that high, and average rates in the Soviet Arctic seem to be still higher (Tomirdiaro, 1975).

When considering the actual time frame in which dynamic nearshore processes act in the two different environments, a major discrepancy in erosion rates becomes evident. At lower latitudes the marine forces attacking the coasts are at work for 12 months of the year, while the arctic shoreline retreats only during three summer months. For a majority of the year, and including the period with the severest weather, the arctic shoreline is frozen and stable under a protective covering of snow and ice. Elsewhere during this same period, the greatest coastal damage is done. Using a common denominator then in our comparison of Texas and North Slope erosion rates, we conclude that the latter are at least 8 times higher. This raises the fundamental question: What mechanisms or forces make the Arctic coastal environment more erosive than that of lower latitudes?

\section{ICE AS EROSION AGENT?}

Some workers have attributed the higher erosion rates, and even the characteristic shelf profile of the Arctic largely to thermal processes. In this study, we have shown that after the process of thermal collapse is complete, mechanical energy is still required to transport away large sediment volumes to account for the maintenance of the present shelf profile as the coast retreats. However, wave energy in the classical sense can not account for the rapid erosion of the coast and shelf, and we must consider other sediment transport mechanisms.

Published sediment transport estimates for the littoral zone do not account for the action of floating ice wallowing in a wave train along the shoreface. Reimnitz and Kempema (1982) have demonstrated the formation of large, irregular hydraulic bedforms resulting from the process, but net sediment transport can not be quantified. Calculations of the amount of toe protection required around a hypothetical conical drilling structure in the Arctic, under assumed wave and current conditions, predict erosion of gravel-size sediment out to 20-m water depths (Kobayashi and others, 1981). The effects of ice keels in contact with the bottom or even barely skimming the seabed without actually going aground should be similar. Thus, sediment erosion from hydraulic processes as a result of flow interaction with ice keels probably extends far beyond the $20-\mathrm{m}$ isobath.

In two separate studies, we have shown that bedload movement is rapid far beyond the surf zone. One study of bedload transport, measured at a distance of about $4 \mathrm{~km}$ from shore in water depths of $2.5 \mathrm{~m}$, indicated a rate of $9 \mathrm{~m}^{3} / \mathrm{yr} / \mathrm{m}$ of coastal zone (Reimnitz and Kempema, 1983). This transport was assumed shore parallel, but may have an offshore component. Another study involving repetitive surveys to monitor icegouging rates in Harrison Bay, showed that fall storms obliterated all gouges from the shore to $13-\mathrm{m}$ water depths, at a distance of $15 \mathrm{~km}$ from land (Bames and Reimnitz, 1979). Here also extensive sand movement occurred. The mechanisms by which the sediments were moved are unclear, but we suspect that underwater ice formation (frazil and anchor ice) may play a role. Frazil ice formation during fall storms certainly is involved in the incorporation of large volumes of fine sediment into the seasonal ice canopy in some years (Bames and others, 1982; Osterkamp and Gosink, 1984).

During the winters 1978 and 1979, sediment-laden ice extended out to the stamukhi zone at the $20-\mathrm{m}$ isobath, with concentrations of 243 ton $/ \mathrm{km}^{2}$ and 800 ton $/ \mathrm{km}^{2}$, respectively (Barnes and others, 1982). According to rough calculations the area between the coast and the stamukhi zone, as mapped by Reimnitz and others (1978), covers $3,290 \mathrm{~km}^{2}$ in the study region. Thus, the ice canopy held 0.79 million tons in 1978 , and 2.6 million tons in 1979. In the first of the two winters, the sediment was composed mainly of silt and clay, but sediment samples collected from the ice in 1979 contained as much as 30 percent sand. Sediment held by the winter ice canopy therefore is significant in terms of the overall sediment budget. However, since most of the material is released locally to the water column during the following summer melt, summer rafting of sediment introduced into the fast ice by fall storms can not account for all of the sediment eroded. During the fall storms and the actual production of frazil ice on the inner-shelf, currents may be flowing at a rate of over two 
knots for several days. We believe this may be the time when the greatest amount of sediment is transported away from the region. But severe icing conditions for vessels and oceanographic equipment, and the formation of large volumes of frazil ice, make the transition from summer open-water to winter ice-cover the most difficult season for marine research and therefore also the least known in terms of geologic processes.

Ice gouging and related processes certainly affect sediment transport not only in the littoral zone but across the entire shelf. Reimnitz and Kempema (1984) stated "Grounding ice, chuming and softening bottom deposits and at the same time producing rough relief, makes materials readily available for removal by waves and currents, thereby aiding the winnowing of fine materials." They also discuss the leveling action of large-topographic features by sea ice as a result of the concentration of ice impacts on topographic highs. This leveling action is similar to the smoothing of a rough field by use of a harrow, which knocks off the peaks and fills depressions. The bulldozing action of ice keels in the process of gouging also results in lateral sediment transport. Gouges on the Beaufort Sea shelf are generally parallel to the coast and regional trends of isobaths and are produced by ice plowing from east to west. The typical gouge on the midshelf is about $60 \mathrm{~cm}$ deep, $7.8 \mathrm{~m}$ wide, has flanking ridges $50 \mathrm{~cm}$ high (Bames and others, 1984) and is over a kilometer long. The repetitive rate of gouging of a specific point in this area can be as high as once every two years. Viewed at geologic time scales, the westward displacement of material by bulldozing must be considerable. However, as with previously discussed ice-driven sediment transport processes, this one also remains unquantified.

We must point out, that the preceding discussion of the importance of sea ice for sediment transport and shallow-water topography applies only to ice-stressed coasts and sea-floor areas composed of poorly consolidated materials, where each ice impact leaves a visible scar. These processes seem ineffective, however, in the shaping of high-latitude coastal areas composed of hard and massive rock (for example, Trenhaile, 1983).

\section{SUMMARY AND CONCLUSIONS}

Using two sets of 1:50,000-scale charts, from surveys spaced 30 yrs apart, this study delineates patterns in coastline changes and sediment yields from erosion for $344 \mathrm{~km}$ of Alaska's Beaufort Sea coast. Excluding the large Colville Delta, which advances at an average rate of $0.4 \mathrm{~m} / \mathrm{yr}$, the overall coastline is eroding at a rate of $2.5 \mathrm{~m} / \mathrm{yr}$. In places, the local long-term erosion rates are as high as $18 \mathrm{~m} / \mathrm{yr}$, while accretion rates near the active mouths of the Colville River are as high as $20 \mathrm{~m} / \mathrm{yr}$. The coastal-plain deposits in the western third of the study area are fine-grained mud; here average erosion rates are highest $(5.4 \mathrm{~m} / \mathrm{yr})$. The rest of the study area is composed of sandy to gravelly deposits, which erode at 1.4 $\mathrm{m} / \mathrm{yr}$. This difference suggests that the grain size of bluff material exerts the dominant control on coastal-retreat rates. Other important factors include bluff height, ice content and thaw settling, bluff orientation, and degree of exposure to the marine environment. Vertical crustal motion has not played an important role during Holocene time, as evidenced by the constant elevation of 120,000-yr-old shoreline deposits traceable for $200 \mathrm{~km}$ from Barrow to the Colville River and by 30-yr observations on tidal benchmarks along the Beaufort Sea coast.

In calculating sediment yield, we consider not only the materials in coastal bluffs above sea level, but also the submerged profile to $2-\mathrm{m}$ depths. Assuming this profile to be in dynamic equilibrium, we account for material eroded to a depth of $2 \mathrm{~m}$ below MLLW as the profile migrates landward. The upper part of this roughly 5-m-thick eroded section contains as much as 75 percent ice, and the sediment yield is reduced accordingly in our calculations. The annual yield from coastal retreat thus calculated is 2.5 million $\mathrm{m}^{3}$, with the offshore contribution slightly higher than the onshore contribution. Based on our evaluation of sparse data on sediment carried by Arctic streams, we estimate the annual sediment yield from the adjacent drainage areas is 0.4 million $\mathrm{m}^{3}$, seven times less than that from coastal erosion.

Knowledge of recent patterns in coastal retreat, coupled with knowledge of factors controlling this retreat, allows us to estimate the configuration and location of past and future coastlines. We find no support for the theory that the evolution of coastal embayments and lagoons begins with the breaching and coalescing of large lakes, followed by thaw settlement. Rather, the existence of older, coarse-grained, and erosion-resistant barrier-island and beach deposits exerts a strong influence on the locus and shape of some of the newly forming embayments. Others, however, remain unexplained.

If the present coastal-retreat rates have been sustained since sea level approached its present position about 5,000 yr B.P., then the corresponding ancient shoreline could have ranged from 7 to $27 \mathrm{~km}$ seaward of the present one, in accordance mainly with grain-size variations in coastal bluffs. Furthermore, if erosion occurred only to $2-\mathrm{m}$ water depths, as assumed in our sediment yield calculations, 10 - to $20-\mathrm{km}$-wide and 2-m-deep platforms should be widespread around the Arctic Ocean. Since such wide platforms do not exist, and since we can show that thaw settling contributes much less to the shape of the marine profile in the Arctic than previously proposed, coastal retreat must be associated with erosion reaching to depths much greater than $2 \mathrm{~m}$. The sediment yield therefore could be many times larger than we calculated. From this follows, that coastal retreat rates are not influenced only by composition of subaerial coastal-plain deposits, but by composition of materials eroded on the inner shelf. A growing body of evidence from interpretations of boreholes, seismic-reflection data, foraminifers, clay-mineral distribution, quartz-grain surface textures, and soil-engineering properties of surficial sediments shows that the sea floor of the inner shelf seaward to at least $30-\mathrm{m}$ depth is indeed an erosional surface truncating older strata. Considering the rapid, and deep-reaching erosion, shallow bays, lagoons, and barrier islands do not provide adequate long-term sediment sinks accommodating materials introduced at the present high rates. Modern deposits found in some of these features may be held there for one or two thousand years, but are then reintroduced to the sea as the shelf profile moves through the locality. We therefore conclude that the sediment yield from coastal retreat and rivers largely by-passes the shelf. Part of this sediment flux is seen in form of a 2- to 3-m-thick, transient "roto-till" layer draped over large regions of the open shelf, a result of ice-keels plow- 
ing up underlying strata and mixing these sediments with modern materials and fauna.

Within the conterminous United States, the Gulf of Mexico coast has the highest erosion rates. The Texas coast, fringed by a low coastal plain of unconsolidated sediments, marked by vertical crustal stability, and therefore in some respects similar to that of the Beaufort Sea, retreats about $1.2 \mathrm{~m} / \mathrm{yr}$, or about half the Beaufort Sea average. Since coastal erosion in Arctic regions is restricted to three summer months when waves and coastal currents are active, erosion rates there must be multiplied by a factor of four for a meaningful comparison with the rates of ice-free, low-latitude coasts, which experience waves and currents year round. Accordingly, Arctic erosion rates are 8 times higher than Texas rates. Additionally, Arctic fetches are severely restricted during the navigation season by the ever-present polar ice pack, unlike the long and constant Texas fetch, which allows generation of larger and more pervasive waves. Lastly, most of the damage to low-latitude coastlines is done by winter storms, when the Arctic coastline is well protected by ice. Classic wave theory therefore can not account for the sediment dynamics of the Arctic coastal zone. We feel that processes here are driven largely by sea ice acting as the most important geologic agent.

Considering the rapid shoreline development by petroleum industry, our inadequate understanding of Arctic coastal processes begs for accelerated research in this region.

\section{ACKNOWLEDGMENTS}

We received much information and help from Stewart Rawlinson in the initial stages of this study, and thank him for sharing his data. Personal insights of Paul Sellmann broadened the scope of this investigation. His constructive criticism and review, together with those by Doug Inman and Dave Hopkins are gratefully acknowledged. Len Gaydos and William Acevedo provided advice and enhanced Landsat imagery for figure 20. Jim Dailey helped us determine the vintage of data sets used in delineation of the coastline in the original base maps. Austin Kovacs provided us with several photos of key localities in the study area. Ed Kempema assisted in the final compilation of the manuscript and figures. We thank them all!

This study was funded in part by the Minerals Management Service through interagency agreement with the National Oceanic and Atmospheric Administration, as part of the Outer Continental Shelf Environmental Assessment Program.

\section{REFERENCES CITED}

Alaska Photogrammetric Consultants Group, 1981, Beaufort Sea Coastal Mapping West Area, State of Alaska, Department of Natural Resources, Division of Technical Services, Coastal and Marine Boundary Section, Anchorage, Alaska, Contract: GSC-376, Anchorage, Alaska, Appendices A-KK, $44 \mathrm{p}$.

Alaska Photogrammetric Consultants, Group, 1982, Beaufort Sea Coastal Mapping East Area, State of Alaska, Department of Natural Resources, Division of Technical Serrvices, Coastal and Marine Boundary Section, Anchorage, Alaska, Contract: GSC-376, Anchorage, Alaska, Appendices A-Q, 33 p.
Arden, R.S., and Wigle, T.S., 1972, Dynamics of ice formation in the upper Niagara River, in International Symposium on the Role of Snow and Ice in Hydrology, Banff, Alberta: v. 2, United Nations Educational, Scientific and Cultural Organization-World Meterological OrganizationInternational Association of Hydrological Sciences, p. 1296-1313.

Arnborg, Lennart, Walker, H.J., and Peippo, Johan, 1967, Suspended load in the Colville River, Alaska, 1962: Geografiska Annaler, v. 49 Series A, no. 2-4, p. 131-144.

Barnes, P.W., 1982, Marine ice-pushed boulder ridge: Arctic, v. 35 , no. 2, p. 312-316.

Bames, P.W., McDowell, David, and Reimnitz, Erk, 1978, Ice gouging characteristics: Their changing patterns from 19751977, Beaufort Sea, Alaska: U.S. Geological Survey OpenFile Report 78-730, 42 p.

Barnes, P.W, Rearic, D.M., and Reimnitz, Erk, 1984, Ice gouging characteristics and processes, in Barnes, P.W., Schell, D.M., and Reimnitz, Erk, eds., The Alaskan Beaufort Sea: Ecosystems and Environments: Academic Press Inc., Orlando, Florida, p. 185-212.

Barnes, P.W., and Reimnitz, Erk, 1973, The shore fast ice cover and its influence on the currents and sediment along the coast of northern Alaska: EOS, American Geophysical Union, v. 54, p. 1108.

1974, Sedimentary processes on arctic shelves off the northern coast of Alaska, in Reed, J.C. and Sater, J.E., eds., The Coast and Shelf of the Beaufort Sea: Arctic Institute of North America, Arlington, Virginia, p. 439-476.

1979 , Ice gouge obliteration and sediment redistribution event; 1977-1978, Beaufort Sea, Alaska: U.S. Geological Survey Open-File Report 79-848, 22 p.

Bames, P.W., Reimnitz, Erk, and Fox, Dennis, 1982, Ice rafting of fine-grained sediment, a sorting and transport mechanism, Beaufort Sea, Alaska: Joumal of Sedimentary Petrology, v. 52, no. 2, p. 493-502.

Barnes, P.W., Reimnitz, Erk, Smith, G.L., and Melchior, John, 1977, Bathymetric and shoreline changes, northwestern Prudhoe Bay, Alaska: U.S. Geological Survey Open-File Report 77-167, 15 p.

Black, R.F., 1964, Gubik Formation of Quaternary age in northern Alaska: U.S. Geological Survey, Professional Papęr 302-C, p. C59-C91.

Black, R.F., and Barksdale, W.E., 1949, Oriented lakes of northern Alaska: Journal of Geology, v. 57, p. 105-118.

Brigham, J.K., Hopkins, D.M., Carter, L.D., and Miller, G.H., 1980, Application of amino acid geochronology to deposits of the arctic coastal plain, Alaska: preliminary results and implications, in Proceedings of the Ninth Annual Arctic Workshop, April 4 and 5, 1980: Institute of Arctic and Alpine Research, University of Colorado, Boulder, Colorado, p. 34-35.

Bruun, Per, 1962, Sea level rise as cause of shore erosion: American Society of Civil Engineers Proceedings, Joumal of the Waterways and Harbors Division, v. 88, no. WW1, p. 117-130.

Cannon, P.J., 1979, The environmental geology and geomorphology of the barrier island-lagoon system along the Beaufort Sea coastal plain, in Environmental Assessment of the Alaskan Continental Shelf, National Oceanic and 
Atmospheric Administration, Annual Reports: v. 10, p. 209-248

Cannon, P.J., and Rawlinson, S.E., 1981, Environmental geology and geomorphology of the barrier island-lagoon system along the Beaufort Sea coastal plain from Prudhoe Bay to the Colville River: U.S. Department of Commerce, National Oceanic and Atmospheric Adiministration, Outer Continental Shelf Environmental Assessment Program Final Report 34 (1985), p. 357-444 + 15-map supplement.

Carson, C.E., and Hussey, K.M., 1959, The multiple-working hypothesis as applied to Alaska's oriented lakes: Proceedings of the lowa Academy of Sciences, v. 66, p. 334-349.

1962, The oriented lakes of arctic Alaska: Joumal of Geology, v. 70, p. 417-439.

Carter, D.L., 1983, Cenozoic glacial and glaciomarine deposits of the central north slope, Alaska, in Thorson, R.M. and Hamilton, T.D., eds., Glaciation in Alaska: extended abstracts from a workshop, Occasional Paper: Alaskan Quaternary Center, University of Alaska Museum, Fairbanks, Alaska, p. 17-21.

Carter, D.L., O'Neil, J.R., and Stipp, J.J., 1985, High sea level along the Alaskan Arctic coast about 70 or $80 \mathrm{ka}$ : Evidence for an Antarctic ice-surge?: 14th Arctic Workshop, Arctic Land-Sea Interaction, Abstracts, Bedford Institute of Oceanography, Dartmouth, Nova Scotia, Canada, p. 22-24.

Carter, D.L., and Robinson, S.W., 1981, Minimum age of beach deposits north of Teshekpuk Lake, Alaskan Arctic coastal plain, in Albert, N.R. and Hudson, T.L., eds., United States Geological Survey in Alaska: Accomplishments during 1979: Geological Survey Circular 823-B: p. B8-B9.

Curray, J.R., 1964, Transgressions and regressions, in Miller, R.L., ed., Papers in marine geology- Shepard Commemorative Volume: McMillan Company, New York, p. 175-203.

Dionne, J.C., 1973, La notion de pied de glace (icefoot), en particulier dans l'estuaire du Saint-Laurent: Cahiers de Geographie de Quebec, v. 17, no. 41, p. 221-250.

Dunton, K.H., Reimnitz, Erk, and Schonberg, Susan, 1982, An arctic kelp community in the Alaskan Beaufort Sea: Arctic, v. 35 , no. 4 , p. $465-484$.

Dygas, J.A., and Burrell, D.C., 1976, Dynamic sedimentological processes along the Beaufort Sea coast of Alaska, in Assessment of the Arctic Marine Environment: Selected Topics: Institute of Marine Sciences, University of Alaska, Fairbanks, Alaska, p. 189-203.

Dygas, J.A., Tucker, Robert, and Burrell, D.C., 1972, Geologic report of the heavy minerals, sediment transport, and shoreline changes of the barrier islands and coast between Oliktok Point and Beechey Point, in Kinney, P.J., D.M. Schell, Vera Alexander, D.C. Burrell, Robert Cooney, A.S. Naidu, eds., Baseline data study of the Alaskan Arctic aquatic environment: University of Alaska International Marine Sciences Report R72-3, p. 62-121.

Forbes, D.L., 1981, Babbage River delta and lagoon: hydrology and sedimentology of an arctic estuarine system: Vancouver, British Columbia, Department of Geography, University of British Columbia, Ph.D. dissertation, 554 p.

Harper, J.R., 1978, The physical processes affecting the stability of tundra cliff coasts: Department of Marine Sciences, Louisiana State University, Baton Rouge, Louisana, Ph.D. disseration, $212 \mathrm{p}$.

Harper, J.R., Owens, E.H., and Wiseman, W.J., Jr., 1978, Arc- tic beach processes and the thaw of ice-bonded sediments in the littoral zone: Proceedings of the 3rd International Permafrost Conference, Washington, D.C., National Academy of Sciences, p. 195-199.

Harrison, D.W., and Osterkamp, T. E., 1981, Subsea permafrost: probing, thermal regime and data analysis: Environmental Assessment of the Alaskan Continental Shelf, Annual Reports of Principal Investigators for the year, U.S. Department of Commerce, v. 7: Hazards, p. 291350.

Hartz, R.W., 1978, Erosional hazards map of the arctic coast of the National Petroleum Reserve, Alaska: U.S. Geological Survey Open-File Report 78-406, 8 p.

Hodel, Karen, 1985, Microfeatures of quartz grains from modern Arctic terrestrial and subaqueous environments, North Slope, Alaska: Berkeley, Calif., University of California, M.S. thesis, 69 p.

Holmquist, Charlotte, 1978, Lakes of polar regions: age, complexity, and trophic state: Proceedings of the International Association of Theoretical and Applied Limnologists, v. 20, no. 1, p. 615-617.

Hopkins, D.M., and Carter, L.D., 1980, Discrepancy in correlation of transgressive marine deposits of Alaska and the eastern Arctic, in Proceedings of the Ninth Annual Arctic Workshop: Institute of Arctic and Alpine Research, University of Colorado, Boulder, Colorado, p. 12-13.

Hopkins, D.M., and Hartz, R.W., 1978, Coastal morphology, coastal erosion and barrier islands of the Beaufort Sea, Alaska: U.S. Geological Survey Open-File Report 78-1063, p. 54.

Hume, J.D., and Schalk, M., 1964, The effects of ice push on Arctic beaches: American Journal of Science, v. 262, p. 267-273.

Inman, D.L., and Brush, B.M., 1973, The coastal challenge: Science, v. 181 , p. $20-32$.

Inman, D.L., and Chamberlain, T.K., 1960, Littoral sand budget along the southern California coast, in Report of the Twenty-first International Geological Congress, Abstracts: Copenhagen, p. 245-246.

Klyuyev, Ye. V., 1965, The role of permafrost factors in the dynamics of bottom topography in polar seas: Oceanology, Academy of Sciences of the U.S.S.R., v. 5, no. 1, p. 78-83.

Kobayashi, Nobuhisa, Vivatrat, Vitoon, Madsen, O.S., and Boaz, I.B., 1981, Erosion prediction for exploration and production structures in the Arctic: 13th Annual Offshore Technology Conference, Houston, Texas, v. OTC paper no. 4114, p. $459-472$.

Kovacs, Austin, 1983, Shore ice ride-up and pile-up features, Part I: Alaska's Beaufort Sea coast: Cold Region Research and Engineering Lab, Report 83-9, U.S. Army Corp of Engineers, Hanover, New Hampshire, 59 p.

1984, Shore ice ride-up and pile-up features, Part II: Alaska Beaufort Sea coast - 1983 and 1984: Cold Region Research and Engineering Lab Report 84-26, U.S. Army Corps of Engineers, Hanover, New Hampshire, 29 p.

Lachenbruch, A.T., 1985, Temperature and depth of permafrost on North Slope, Alaska: American Association of Petroleum Geologists, Bulletin, v. 69, no. 4, p. 667-668.

Lachembruch, A.T., Sass, J.H., Marshall, B.V., and Moses, T.H., 1982, Permafrost, heat flow, and the geothermal regime at Prudhoe Bay, Alaska: Joumal of Geophysical 
Research, v. 87, no. B11, p. 9301-9316.

Lee, H.J., Winters, W.J., and Chamberlain, E.J., 1985, Geothechnical properties and freeze/thaw consolidation behavior of sediment from the Beaufort Sea, Alaska: U.S. Geological Survey Open-File Report 85-612, 83 p.

Leffingwell, E. de K., 1919, The Canning River region, northern Alaska: U.S. Geological Survey Professional Paper 109, $251 \mathrm{p}$.

Lewellen, R.I., 1977, A study of Beaufort Sea coastal erosion, northern Alaska: U.S. Department of Commerce, National Oceanic and Atmospheric Administration, Annual Report, v. 14, p. 491-528.

Livingstone, D.A., 1954, On the orientation of lake basins: American Journal of Science, v. 252, p. 547-554.

Martin, Seelye, 1981, Frazil ice in rivers and oceans, in Annual Reviews of Fluid Mechanics: Annual Reviews Inc., v. 13, p. $379-397$.

Matthews, J.B., 1981, Circulation in the Sale 71 area, in Norton, D.W and Sackinger, W.M., eds., Beaufort Sea Sale 71 Synthesis Report: U.S. Department of Commerce, National Oceanic and Atmospheric Administration, Boulder, Colorado, p. 71-178.

May, S.K., Dolan, Robert, and Hayden, B.P., 1983, Erosion of U.S. shorelines: EOS, Transactions, American Geophysical Union, p. 521-522.

McLaren, Patrick, 1982, The coastal geomorphology, sedimentology and processes of eastern Melville and western Byam Martin Islands, Canadian Arctic archipelago: Geological Survey of Canada, Bulletin, no. 333, 39 p.

McDonald, B.C., and Lewis, C.P., 1973, Geomorphic and sedimentologic processes of rivers and coasts, Yukon coastal plain: Environmental-Social Commission, Northern Pipeline, Task Force on Northern Oil Development, Report 73-79, 245 p.

Milliman, J.D., and Meade, R.H., 1983, World-wide delivery of river sediment to the oceans: The Journal of Geology, v. 91, p. 1-21.

Moore, D.G., and Curray, J.R., 1964, Wave-base, Marine profile of equilibrium and wave-built terraces: Discussion: Geological Society of America Bulletin, no. 75, p. 12671273.

Morack, J.L., and Rogers, J.C., 1981, Seismic evidence of shallow permafrost beneath islands in the Beaufort Sea, Alaska: Arctic, v. 34, no. 2, p. 169-174.

National Research Council, Marine Board, Understanding the Arctic sea floor for engineering purposes, 1982, Committee on Arctic Seafloor Engineering, Marine Board Commission on Engineering and Technical Systems, National Research Council, National Academy Press, Washington, D.C., 141 p.

Naidu, A.S., and Mowatt, T.C., 1983, Sources and dispersal patterns of clay minerals in surface sediments from the continental shelf areas off Alaska: Geological Society of America Bulletin, v. 94, p. 841-854.

Naidu, A.S., Mowatt, T.C., Rawlinson, S.E., and Weiss, H.V., 1984, Sediment characteristics of the lagoons of the Alaskan Beaufort Sea coast and evolution of Simpson Lagoon, in Barnes, P.W., Schell, D.M., Reimnitz, Erk, eds., The Alaskan Beaufort Sea: Ecosystems and Environments: Academic Press Inc., Orlando, Florida, p. 275-292.

Nummedal, Dan, 1979, Coarse-grained sediment dynamics Beaufort Sea, Alaska., in Proceedings of port and ocean engineering under Arctic conditions: Norwegian Institute of Technology, p. 845-858.

Osterkamp, T.E., 1978, Frazil ice formation: a review: Journal of the Hydraulics Division, American Society of Civil Engineers, v. 104, no. HY9, p. 1239-1255.

Osterkamp, T.E., and Gosink, J.P., 1984, Observations and analyses of sediment laden sea ice, in Barnes, P.W., Schell, D.M., and Reimnitz, Erk, eds., The Alaskan Beaufort Sea: Ecosystems and Environments: Acadaemic Press Inc., Orlando, Florida, p. 73-94.

Owens, E.H., 1982, Ice foot, in Schwartz, M.L., ed., Encyclopedia of Beaches and Coastal Environments: Hutchinson Ross Publishing Company, Stroudsburg, Pennsylvania, p. 480-481.

Owens, E.H., and Harper, J.R., 1977, Frost-table and thaw depth in the littoral zone near Peard Bay, Alaska: Arctic, v. 30 , no. 3, p. $155-168$.

Owens, E.H., Harper, J.R., and Nummedal, Dan, 1980, Sediment transport processes and coastal variability on the Alaskan North Slope, in Proceedings of the 17th International Coastal Engineering Conference: American Society of Civil Engineers, Sydney, Australia, p. 1344-1363.

Reimnitz, Erk, and Barnes, P.W., 1974, Sea ice as a geologic agent on the Beaufort Sea shelf of Alaska, in Reed. J.C. and Sater, J.E., eds., The Coast and Shelf of the Beaufort Sea: Arctic Institute of North America, Arlington, Virginia, p. 301-353.

Reimnitz, Erk, Barnes, P.W., and Phillips, R.L., 1984, Geological evidence for 60 meter deep pressure-ridge Keels in the Arctic Ocean: Proceedings, International Association of Hydraulic Research, 7th International Symposium on Ice, Hamburg, Germany, v. II, p. 189-206.

Reimnitz, Erk, Barnes, P.W., Rearic, and others, 1982, Marine geological Investigations in the Beaufort Sea in 1981 and preliminary interpretations for regions from the Canning River to the Canadian Border: U.S. Geological Survey Open-File Report 82-974, 46 p.

Reimnitz, Erk, and Bruder, K.F., 1972, River discharge into an ice-covered ocean and related sediment dispersal, Beaufort Sea, coast of Alaska: Geological Society of America Bulletin, v. 83, no. 3, p. 861-866.

Reimnitz, Erk, Graves, S.M., and Barnes, P.W., 1985, Beaufort Sea coastal erosion, shoreline evolution and sediment flux: U.S. Geological Survey Open-File Report 85380,67 p.

Reimnitz, Erk, and Kempema, E.W., 1982, Dynamic icewallow relief in northern Alaska's nearshore: Journal of Sedimentary Petrology, v. 52, no. 2, p. 451-462.

1983, High rates of bedload transport measured from the infilling rate of large strudel-scour craters in the Beaufort Sea, Alaska: Continental Shelf Research, v. 1, no. 3, p. 237-251.

1984, Pacific ice interaction with stamukhi shoal, in Barnes, P.W., Schell, D.M., and Reimnitz, Erk, eds., The Alaskan Beaufort Sea: Ecosystems and Environments: Academic Press Inc., Orlando, Florida.

Reimnitz, Erk, and Maurer, D.K., 1979, Effects of storm surges on the Beaufort Sea coast, northern Alaska: Arctic, v. 32 , no. 4, p. $329-344$.

Reimnitz, Erk, Toimil, L.J., and Barnes, P.W., 1978, Arctic continental shelf morphology related to sea-ice zonation, 
Beaufort Sea, Alaska: Marine Geology, v. 28, p. 179-210.

Rex, R.W., 1961, Hydrodynamic analysis of circulation and orientation of lakes in northern Alaska, in Raasch, G.O., ed., Geology of the Arctic: v. 2, University of Toronto Press, Toronto, Canada , p. 1021-1043.

Rosen, P.S., 1978a, A regional test of the Bruun Rule on shoreline erosion: Marine Geology, v. 26, p. M7-M16. $1978 \mathrm{~b}$, Predicting beach erosion as a function of rising water level: Discussion: Journal of Geology, v. 86, no. 6, p. 763-764.

Sadler, H.E., and Serson, H.V., 1981, Fresh water anchor ice along an arctic beach: Arctic, v. 34 , no. 1, p. 62-63.

Schwartz, M.L., 1967, The Bruun Theory of sea-level rise as a cause of shore erosion: Journal of Geology, v. 75 , no. 1, p. 76-92.

Sejrup, H.P., Miller, G.H., Brigham-Grette, Julie, and others, 1984, Amino acid epimerization implies rapid sedimentation rates in Arctic Ocean cores: Nature, v. 310, p. 772-775.

Sellmann, P.V., Brown, Jerry, Lewellen, R.I., and others 1975 , The classification and geomorphic implications of thaw lakes on the arctic coastal plain, Alaska: Cold Region Research and Engineering Laboratory, Research Report 344, U.S. Army Corps of Engineers, Hanover, New Hampshire, $21 \mathrm{p}$.

Sellmann, P,V, Weeks, W.F., and Campbell, W.J., 1975, Use of side-looking airborne radar to determine lake depth on the Alaskan North Slope, in Cold Regions Research and Engineering Laboratory, Special Report 230, 6 p.

Short, A.D., 1973, Beach dynamics and nearshore morphology of the Alaskan Arctic coast: Department of Marine Science, Louisiana State University, Baton Rouge, Louisiana, Ph.D. dissertation, p 140.

Short A.D., Coleman, J. M., and Wright, L. D., 1974, Beach dynamics and nearshore morphology of the Beaufort Sea coast, Alaska, in Reed, J.C. and Sater, J.E., eds., The Coast and Shelf of the Beaufort Sea: Arctic Institute of North America, Arlington, Virginia, p. 477-488.

Smith, Peggy, 1985, Late Quaternary Geology of the Beaufort Sea Inner Shelf near Prudhoe Bay, in Bartch-Winkler, S. and Reed, K.M., eds., U.S. Geological Survey Circular 945, Accomplishments during 1983, p. 100-103.

Swift, D.J.P., 1968, Coastal erosion and transgressive stratigraphy: Journal of Geology, v. 76, p. 444-456.

Taylor, R.B., 1980, Beach thaw depth and the effect of icebonded sediment on beach stability, in Proceedings of the Canadian Coastal Conference, Burlington, Ontario, April 22-24, 1980, p. 103-121.
Tomirdiaro, S.V., 1975, Thermo abrasion-induced shelf formation in the eastern arctic seas of the USSR during the Holocene: Earth Science Sections, v. 219, no. 1-6, p. 23-26.

Trenhaile, A.S., 1983, The development of shore platforms in high latitudes, in Smith, D.E. and Dawson, A.G., eds., Shorelines and Isostacy: Academic Press Inc., New York, N.Y., p. 77-93.

Tsang, Gee, 1982, Frazil and anchor ice: a monograph: National Research Council, Subcommittee on hydraulics of ice covered rivers, Ottawa, Ontario, Canada, 90 p.

Weeks, W.F., and Weller, M.W., 1984, Offshore oil in the Alaskan Arctic: Science, v. 225, no. 4660, p. 371-378.

Weller, M.W., and Derksen, D.V., 1979, The geomorphology of Teshekpuk Lake in relation to coastline configuration of Alaska's coastal plain: Arctic, v. 32, no. 2, p. 152-160.

Williams, J.R., Yeend, W.E., Carter, L.D., and Hamilton, T.D., 1977, Preliminary surficial deposit map of National Petroleum Reserve: U.S. Geological Survey Open-File Report 77-868.

Wilson, H.P., 1974, Winds and currents in the Beaufort Sea, in Reed, J.C., and Sater,J.E., eds., The Coast and Shelf of the Beaufort Sea: Arctic Institute of North America, Arlington, Virginia, p. 13-23.

Winant, C.D., Inman, D.L., and Nordstrom, C.E., 1975, Description of seasonal beach changes using empirical eigenfunctions: Journal of Geophysical Research, v. 80, no. 15 , p. $19-79$.

Wiseman, W.J., Coleman, J.M., Gregory, A., and others, 1973, Alaskan arctic coastal processes and morphology: Coastal Studies Institute, Techical Report, 149, Louisiana State University, Baton Rouge, Louisana, 171 p.

Wolf, S.C., Reimnitz, Erk, and Barnes, P.W., 1985, Pleistocene and Holocene seismic stratigraphy between the Canning River and Prudhoe Bay, Alaska: U.S. Geological Survey Open-File Report 85-549, 26 p.

Zenkovich, V.P., 1985, Arctic USSR, in Bird, E.C.F., and Schwartz, M.L., eds., The World's Coastline: Van Nostrand Reinhold Company, New York, p. 863-871. 

